\title{
Van een leven lang leren naar een leven lang ontwikkelen
}

Citation for published version (APA):

de Grip, A. (2021). Van een leven lang leren naar een leven lang ontwikkelen: De veranderende betekenis van het post-initieel leren. ROA. ROA External Reports https://doi.org/10.26481/spe.20210624ag

Document status and date:

Published: 24/06/2021

DOI:

10.26481/spe.20210624ag

Document Version:

Publisher's PDF, also known as Version of record

\section{Please check the document version of this publication:}

- A submitted manuscript is the version of the article upon submission and before peer-review. There can be important differences between the submitted version and the official published version of record.

People interested in the research are advised to contact the author for the final version of the publication, or visit the DOI to the publisher's website.

- The final author version and the galley proof are versions of the publication after peer review.

- The final published version features the final layout of the paper including the volume, issue and page numbers.

Link to publication

\footnotetext{
General rights rights.

- You may freely distribute the URL identifying the publication in the public portal. please follow below link for the End User Agreement:

www.umlib.nl/taverne-license

Take down policy

If you believe that this document breaches copyright please contact us at:

repository@maastrichtuniversity.nl

providing details and we will investigate your claim.
}

Copyright and moral rights for the publications made accessible in the public portal are retained by the authors and/or other copyright owners and it is a condition of accessing publications that users recognise and abide by the legal requirements associated with these

- Users may download and print one copy of any publication from the public portal for the purpose of private study or research.

- You may not further distribute the material or use it for any profit-making activity or commercial gain

If the publication is distributed under the terms of Article $25 \mathrm{fa}$ of the Dutch Copyright Act, indicated by the "Taverne" license above, 


\section{Maastricht University}

\section{Prof.dr. Andries de Grip}

School of Business and Economics

\section{Van een leven lang leren naar een leven lang ontwikkelen}

De veranderende betekenis van het post-initieel leren

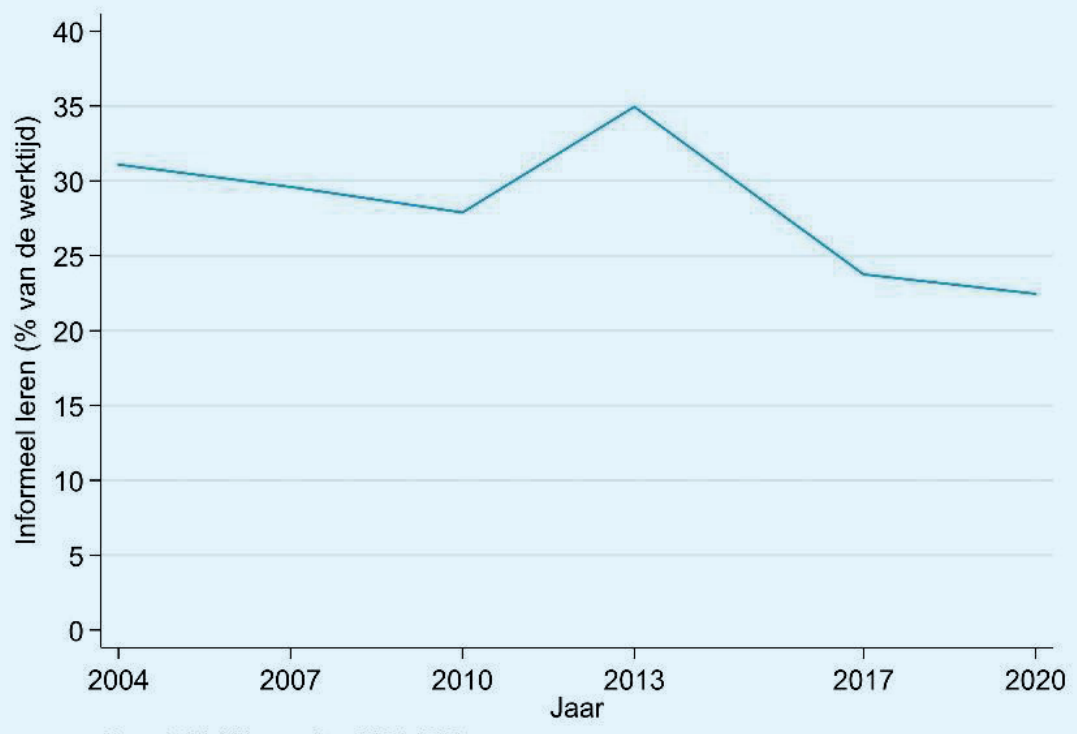




\section{Van een leven lang leren naar een leven lang ontwikkelen \\ De veranderende betekenis van het post-initieel leren}


ISBN: 978-90-5321-603-3

(C) Andries de Grip 2021. Alle rechten voorbehouden. 


\title{
Van een leven lang leren naar een leven lang ontwikkelen
}

\author{
De veranderende betekenis van het \\ post-initieel leren
}

Rede uitgesproken bij het afscheid als hoogleraar Bedrijfs- en Beroepsscholing en Arbeidsmarkt aan de School of Business and Economics van de Universiteit Maastricht

Maastricht, 24 juni 2021

door Prof.dr. Andries de Grip 
Mevrouw de rector, collega's, vakgenoten, familie, vrienden en bekenden, zeer gewaardeerde toeschouwers,

Bij zowel overheden als bedrijven is er vaak meer aandacht voor het maken van beleid dan voor het evalueren van het beleid. Bij de Rijksoverheid is dat evident als we kijken naar het verschil in belangstelling voor Prinsjesdag, waar de regering haar plannen voor het komende jaar bekend maakt en voor Verantwoordingsdag (de derde woensdag in mei), waarop gekeken wordt naar de effectiviteit van het gevoerde beleid. En in alle eerlijkheid: ook bij hoogleraren is er vaak meer interesse in de plannen die een hoogleraar uitspreekt in haar of zijn oratie dan in de afscheidsrede. Maar ik wil deze afscheidsrede wel in het teken zetten van de taakstelling die ik mijzelf oplegde in mijn oratie die ik op 29 september 2000 uitsprak. Dat heeft bovendien de voor mij prettige bijkomstigheid dat ik ongegeneerd naar mijn eigen werk kan verwijzen.

Mijn oratie had als titel: Van tweedekansonderwijs naar een leven lang leren: De veranderende betekenis van post-initiële scholing. Hierin benadrukte ik dat de maatschappelijke noodzaak om de participatie in het post-initieel onderwijs te vergroten niet langer in het teken stond van het versterken van het tweedekansonderwijs, maar in het teken van het adequaat inspelen op de verschuivingen in de op de arbeidsmarkt gevraagde kennis en vaardigheden. Daarbij is er niet langer sprake van een substitutie tussen de investeringen in initieel en post-initieel leren, maar veeleer van een complementariteit 
tussen beide investeringen. We moeten gewoon meer leren dan in het verleden.

Dat geldt nog steeds. Het postinitiële leren staat momenteel meer dan ooit in het teken van de dynamiek op de arbeidsmarkt. Naast de upgrading van de gevraagde competenties in veel functies is er ook sprake van competentieveroudering. Deze competentieveroudering ontstaat omdat er door technologische en organisatorische vernieuwingen in de productieprocessen van vrijwel alle sectoren van de economie steeds nieuwe kennis en vaardigheden nodig zijn om je werk goed te kunnen doen. Maar daar is nog wat bijgekomen, waardoor de uitdagingen nog groter zijn geworden. In de afgelopen 15 jaar is de pensioengerechtigde leeftijd flink naar achteren geschoven, waardoor we veel langer onze competenties op peil moeten houden dan in het verleden. Al heeft ieder nadeel ook zijn voordeel: Het verschuiven van de pensioneringsleeftijd heeft mij in de gelegenheid gesteld langer aan mijn leeropdracht te kunnen werken dan destijds de bedoeling was.

Het maatschappelijk effect van de verschillende herzieningen van ons pensioenstelsel is echter veel groter geweest dan die bijna anderhalf jaar, waarmee de AOW-leeftijd is opgeschoven. Volgens cijfers van het CBS steeg de gemiddelde pensioenleeftijd van werknemers tussen 2006 en 2020 van bijna 61 naar 65 jaar en 6 maanden. Hierdoor is het aantal mensen van 55 jaar of ouder dat werkzaam is tussen 2006 en 2020 verdubbeld. Ons menselijk kapitaal moet dus gemiddeld 4,5 jaar langer upto-date blijven om goed inzetbaar te blijven op de arbeidsmarkt. 
Deze grote maatschappelijke noodzaak tot een leven lang leren (LLL) of zoals momenteel vaak wordt gezegd een leven lang ontwikkelen (LLO), roept een aantal vragen op, waarop ik in deze lezing zal ingaan:

1. Hoe houden we onze competenties up-to-date?

2. Hoe effectief is het LLO voor de productiviteit van werkenden?

3. Hoe effectief is het LLO voor de duurzame inzetbaarheid van werkenden?

4. Voor welke groepen is het moeilijk om in de toenemende noodzaak van een LLO te voorzien?

5. Welke maatschappelijk infrastructuur op het terrein van het LLO heeft onze samenleving nodig om een sterke economie te blijven?

Bij het beantwoorden van deze vragen zal ik in het bijzonder ingaan op het onderzoek dat binnen het kader van mijn leeropdracht vanuit het ROA heeft plaatsgevonden.

\section{Hoe houden we onze competenties up-to-date?}

Het ROA onderzoek van de afgelopen twee decennia is een belangrijke bron om deze vraag te kunnen beantwoorden. In mijn oratie had ik mij er nog over verwonderd hoe weinig we destijds wisten van de omvang en de aard van de investeringen in menselijk kapitaal in ons land. Terwijl het hier toch gaat om de belangrijkste productiefactor in onze kenniseconomie. Zo was er destijds alleen wat verbrokkelde informatie beschikbaar over de deelname aan cursussen en trainingen, maar was er 
geen enkel inzicht in de omvang van het informele leren op het werk. Hoewel er zowel in de economische (Arrow, 1962; Killingsworth, 1982; Mincer, 1974), als onderwijskundige literatuur (Eraut, 2004) al langer het besef was hoe belangrijk het learning by doing op de werkvloer is, was de moeilijke meetbaarheid daarvan een belangrijke reden voor de geringe aandacht hiervoor in de beleidsdiscussies.

Met de eerste ROA Levenslang Leren enquête die ik in 2004 samen met Lex Borghans en Bart Golsteyn heb opgezet, hebben we een unieke databron weten te creëren, die een belangrijke bijdrage heeft geleverd aan het inzicht dat we nu hebben in de aard van het LLO, de deelname eraan en de effectiviteit ervan (Borghans, Golsteyn en de Grip, 2006 en 2007). Bekostigd uit verschillende bronnen hebben we de ROA Levenslang Leren enquête min of meer elke drie jaar herhaald (Borghans cs. 2011 en 2014; Fouarge cs. 2009 en 2018). Eind 2020 is opnieuw een LLL enquête uitgezet, waarvan ik u hier enkele cijfers laat zien.

\section{Het volgen van cursussen en trainingen}

Figuur 1 geeft een overzicht van de deelname aan cursussen en trainingen in Nederland vanaf 2004. De figuur laat zien dat er de afgelopen jaren weinig veranderingen hebben plaatsgevonden in de scholingsdeelname. In alle metingen blijkt ruim de helft van de werkenden in de voorafgaande twee jaar een training of cursus te hebben gevolgd. Na 2013 is dit iets teruggelopen tot $51 \%$ van de werkenden in 2020. Van de nietwerkenden fluctueert de scholingsparticipatie rond de $20 \%$, maar ook onder hen is de scholingsparticipatie in 2020 teruggelopen tot $17 \%$. 
Figuur 1: Ontwikkeling van de deelname aan cursussen en trainingen, 20042020

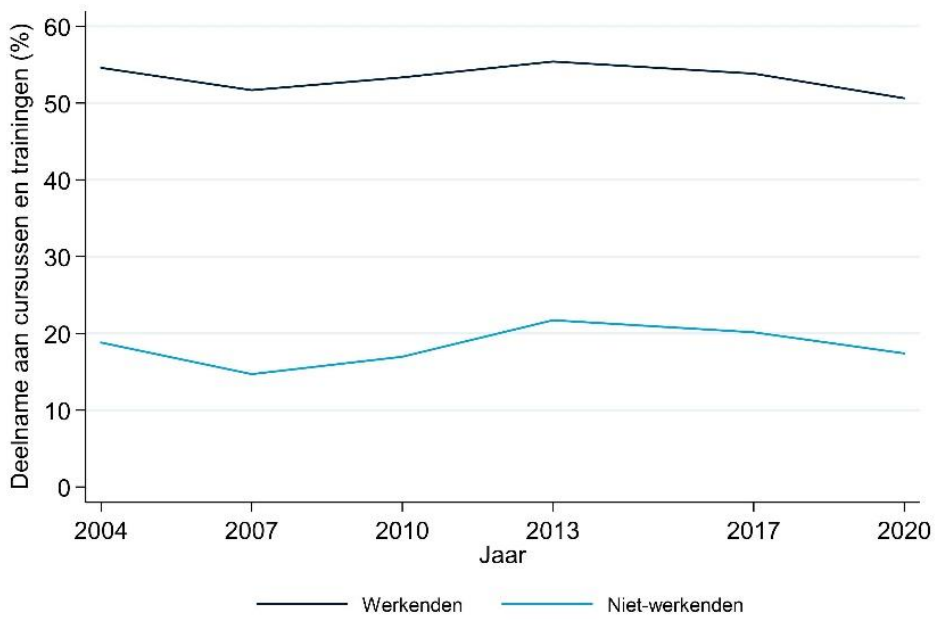
Bron: ROA LLL enquête, 2004-2020

Een vergelijking met andere Europese landen laat zien dat de scholingsdeelname in Nederland weliswaar boven het Europese gemiddelde ligt, maar flink achter blijft bij die in de Scandinavische landen (SCP, 2019). Maar zoals het SCP (2019) ook concludeerde: de scholingsdeelname in Nederland stagneert.

\section{Learning-by-doing}

In het rapport Meer werken is meer leren, waarin we verslag doen van de resultaten van de eerste ROA-LLL enquête, Iaten we voor het eerst in Nederland zien hoe enorm belangrijk het informele leren op het werk is (Borghans cs., 2006). We meten dat door in de enquête de simpele vraag te stellen: Hoeveel 
procent van de werktijd besteedt $u$ aan taken waarvan $u$ kunt leren? Hoewel er op deze subjectieve manier van meten natuurlijk wel wat valt af te dingen, maakt dit het goed mogelijk om het grote belang van het learning-by-doing op maatschappelijk niveau in kaart te brengen. Figuur 2 laat zien dat de werkenden in Nederland tot 2013 zo rond de 30\% van hun werktijd werkzaamheden hebben waarvan zij leren. $\mathrm{Na}$ 2013 is dit percentage flink afgenomen tot $22 \%$ in 2020.

Figuur 2: Informeel leren op het werk: ontwikkeling van het percentage van de werktijd besteed aan activiteiten waarvan men kan leren, 2004-2020

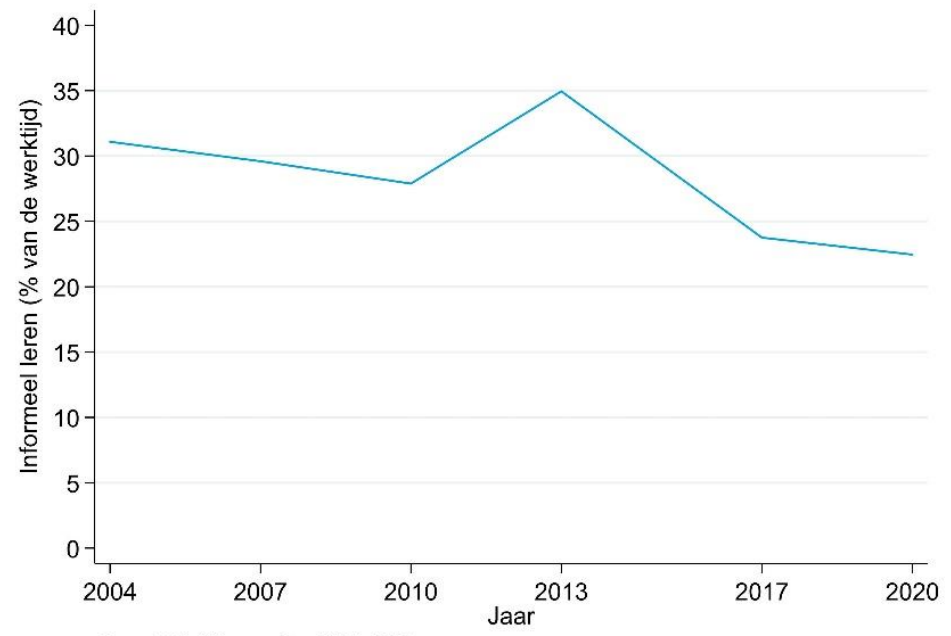

Bron: ROA LLL enquête, 2004-2020

Hoger opgeleiden blijken veel meer werkzaamheden te hebben waarvan zij leren dan lager opgeleiden. En jongeren leren, zoals verwacht mag worden, gemiddeld genomen veel meer van het werk dat zij doen dan ouderen. Dat is 
waarschijnlijk voor een belangrijk deel toe te schrijven aan het feit dat veel oudere werkenden al langere tijd min of meer dezelfde werkzaamheden uitoefenen. Veranderingen in iemands werkzaamheden blijken het informele leren op het werk immers een positieve impuls te geven. Zo ligt de scholingsdeelname ongeveer 5 procentpunten hoger onder werknemers die in de afgelopen twee jaar van werkgever zijn veranderd, of bij hun werkgever van functie zijn veranderd. Ook blijkt dat werkenden die op hun werk te maken hebben met grote technologische of organisatorische ontwikkelingen significant meer van hun werkzaamheden leren (Fouarge cs., 2018). Deze bevindingen wijzen erop dat we veel leren van nieuwe taken. Eerder onderzoek van ons liet dat al zien: Werkenden blijken vooral veel te leren van nieuwe en uitdagende werkzaamheden en relatief weinig van routine werkzaamheden, alsook van vergaderen en overleg (Borghans cs., 2011).

Het relatieve belang van het informele leren op het werk komt vooral goed tot uiting als we het vergelijken met de tijd die werkenden besteden aan het volgen van trainingen en cursussen. Figuur 3 laat zien dat in 2020 gemiddeld 91\% van de totale tijd die werkenden aan werkgerelateerde leeractiviteiten besteden betrekking had op het leren van de werkzaamheden die men heeft. Dit roept natuurlijk wel de vraag op of het effect van het informele leren op het werk niet veel lager is dan wat je leert van het volgen van een cursus of training. Dit blijkt echter niet zo te zijn. Gemiddeld genomen geven werkenden aan dat ze net zoveel leren van een uur informeel 
leren op het werk dan van een uur waarin ze een cursus of training volgen (Fouarge cs., 2018).

Figuur 3: Totale leertijd op het werk onderverdeeld voor een gemiddeld persoon, 2020

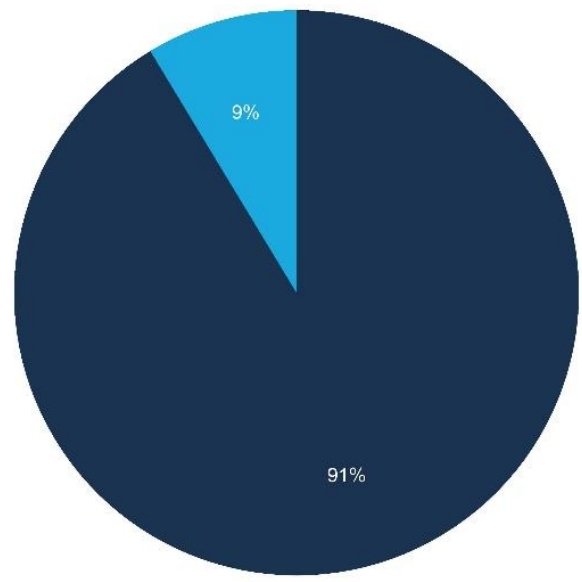

Informeel leren op het werk

Cursusdeelname

Bron: ROA LLL enquête, 2020

Het grote belang van het informele leren op het werk betekent niet dat het volgen van scholing niet belangrijk is. Integendeel: het volgen van een cursus of training is voor 39\% van alle werkenden een stimulans om meer te leren op hun werk. Het volgen van scholing vergroot dus het informele leren op het werk. Daarbij gaat het ook om het in de praktijk met vallen en opstaan toepassen van wat je op een cursus of training hebt geleerd (Van Eldert cs., 2018). 
Het informele leren buiten het werk

Ook buiten het werk kunnen we soms veel op informele wijze leren. In de ROA Levenslang Leren Enquête 2017 hebben we een poging gedaan om een indicatie te krijgen van de mate waarin we leren van activiteiten buiten ons werk. Daarbij hebben we gekeken naar de mate waarin we leren van (1) het verlenen van mantelzorg, (2) het deelnemen aan vrijwilligerswerk en (3) de tijd die we aan kinderen besteden. Zoals verwacht mag worden leren niet-werkenden meer van deze activiteiten dan werkenden, maar ook werkenden blijken naast hun werk nieuwe kennis en vaardigheden op te doen. Figuur 4 geeft een totaaloverzicht van alle werk- en niet-werk gerelateerde leeractiviteiten van werkenden. Hieruit blijkt dat het informeel leren van de taken op het werk nog steeds het overgrote deel van de totale leertijd uitmaakt (67\%). Gemiddeld genomen blijken werkenden echter meer tijd te leren van de aandacht die ze besteden aan kinderen (14\% van de totale leertijd) dan van het volgen van trainingen of cursussen (12\%). Het aandeel van zelfstudie ligt met $5 \%$ van de totale leertijd lager, terwijl zowel vrijwilligerswerk als mantelzorg bij de werkenden gemiddeld slechts $1 \%$ van hun totale leertijd uitmaken. 
Figuur 4: Totale leertijd van werkenden, onderverdeeld voor een gemiddeld persoon, 2017

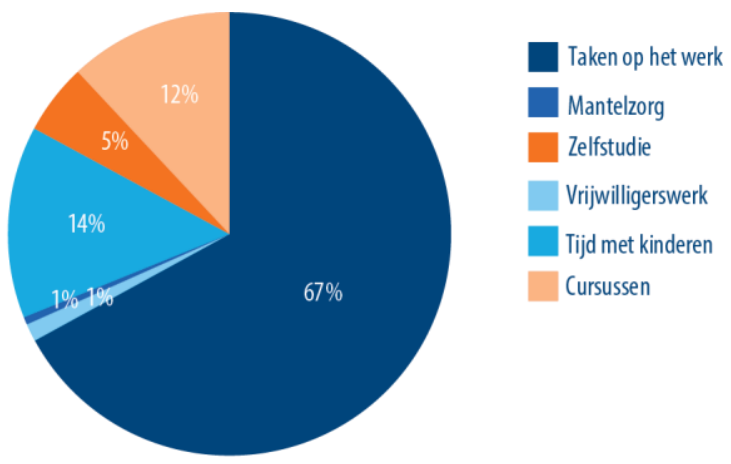

Bron: ROA LL enquête, 2017

\section{Het leren van collega's}

De uitkomsten van de ROA Levenslang Leren Enquête 2017 laten zien dat we op het werk niet alleen leren van de werkzaamheden die we doen, maar ook van onze collega's: $46 \%$ van de werkenden lukte het om de kennis die ze hadden opgedaan in een cursus of training over te dragen aan hun collega's. Al blijken laagopgeleiden hier minder goed in te slagen dan middelbaar- en hoogopgeleiden. Door deze kennisoverdracht heeft een groter deel van de werkenden in het bedrijf profijt van de gevolgde cursussen dan alleen de medewerkers die de cursus zelf hebben gevolgd.

We hebben het leren van collega's ook goed in beeld kunnen brengen in twee studies die we gedaan hebben in een callcenter van een telecommunicatiebedrijf. Zo bleek uit het gerandomiseerde veldexperiment dat ik daar samen met Jan 
Sauermann (De Grip \& Sauermann, 2012) heb gedaan dat er sprake kan zijn van substantiële spillover effecten van het volgen van een scholing. Zo bleek dat als de helft van een team de training had gevolgd, de productiviteit van hun teamgenoten die de training nog niet hadden gevolgd, met $2,5 \%$ toenam. Daarbij werd de productiviteit niet subjectief gemeten zoals in een survey, maar objectief op basis van de Key Performance Indicator (KPI) van het bedrijf. Dit laat zien dat het volgen van scholing nog een groter rendement heeft dan vaak wordt gevonden, want wat iemand leert op een cursus leidt niet alleen tot een grotere productiviteit van degene die de training heeft gevolgd, maar het vergroot ook de productiviteit van de andere leden van het team waarin iemand werkt.

Herbst \& Mas (2015) laten in fraaie meta-analyse zien dat de spill-over effecten van de productiviteit van werkenden op de productiviteit van hun collega's maar liefst $12 \%$ is. Hoewel deze hogere productiviteit ook het gevolg zou kunnen zijn van de druk die iemand voelt om niet achter te blijven bij goed presterende collega's, blijkt uit een studie van Cornelissen, Dustmann \& Schönberg (2017) dat dit laatste vooral het geval is in laaggeschoold werk, terwijl er bij hoger opgeleiden sprake is van wat zij aanduiden als 'knowledge spill-overs'.

In een ander onderzoek in hetzelfde telecommunicatiebedrijf, heb ik samen met Jan Sauermann en Inge Sieben gevonden dat als je ergens gaat werken, je productiviteit sneller toeneemt wanneer je veel kunt leren van je collega's. Zo bleek dat de productiviteit van nieuwe medewerkers die in een team werden geplaatst dat beter presteerde of meer ervaren was, 
significant sneller toenam dan de productiviteit van nieuwe medewerkers die in een minder ervaren team werden geplaatst (De Grip, Sauermann \& Sieben, 2016).

Verschillende studies laten zien dat deze productiviteitstoename verklaard kan worden doordat we op het werk veel leren van de feedback die we krijgen van onze collega's. Dat geldt zowel voor positieve als kritische feedback (Künn-Nelen CS, 2018; Schürmann \& Beausaert (2016), Gerards, De Grip \& Weustink, 2021).

\section{Het leren van externe collega's}

Maar ook buiten het werk kunnen we veel leren van vakgenoten. De eerste studie die daar aandacht aan besteedde was de studie van Darr e.a. (1995) naar de kennistransfers tussen organisaties. Deze studie laat zien dat de communicatie en persoonlijke relaties met mensen die in een soortgelijke functie in andere organisaties werkzaam zijn, heel belangrijk zijn om up-to-date te blijven in je vakgebied. Vanuit dit perspectief kan het erg nuttig zijn om regelmatig naar een workshop of conferentie te gaan, waar je niet alleen kunt luisteren naar de lezingen van experts, maar ook uitgebreid kunt netwerken met andere deelnemers die soortgelijk werk doen. Dit voegt vaak een frisse, vernieuwende blik van buiten het bedrijf toe aan wat je kunt leren van de collega's binnen je eigen organisatie.

De Grip en Pleijers (2019) laten zien dat vooral hoogopgeleiden op deze manier veel leren: $57 \%$ van hen geeft aan in het afgelopen jaar één of meerdere workshops en/of conferenties te hebben gevolgd. Middelbaar opgeleiden (34\%) en laag- 
opgeleiden (15\%) doen dit veel minder. De deelname aan workshops en congressen is het hoogst in de financiële dienstverlening en de sector overheid, onderwijs en gezondheidszorg.

Van een leven lang leren naar een leven lang ontwikkelen Het in kaart brengen van de omvang van het informeel leren heeft een belangrijke functie gehad. Het heeft het belang van het informele leren op de beleidsagenda gezet. Het grote belang van het informele leren voor het op peil en up-to-date houden van onze kennis en vaardigheden rechtvaardigt dan ook dat we niet langer spreken van een leven lang leren, maar van een leven lang ontwikkelen. Immers, gemiddeld 91\% van de totale tijd die werkenden aan leeractiviteiten besteden heeft betrekking op het leren van de taken die ze op hun werk uitvoeren. En daarnaast leren we veel op informele wijze van collega's of op workshops en congressen, alsook van wat we naast ons werk doen.

Het grote belang van het informele leren voor de kennisontwikkeling van de beroepsbevolking maakt ook dat de aandacht zich niet meer louter richt op de scholingsparticipatie, maar steeds meer op het bredere belang van een leerrijk werkklimaat en een goede leercultuur, waarin werkgevers én werknemers zich bewust zijn van de sterk toegenomen maatschappelijke noodzaak tot een leven lang ontwikkelen. Ik zal straks aangeven welke stappen er gezet moeten worden om zo'n goede leercultuur te creëren. 


\section{Hoe effectief is het LLO voor de productiviteit van werkenden?}

Het is niet gemakkelijk om het effect van leeractiviteiten op de productiviteit van werkenden goed te meten. Veel studies hebben dit gedaan door het loon dat iemand verdient als productiviteitsmaatstaf te hanteren, maar daar valt veel op af te dingen, al is het maar dat dit alleen laat zien wat het oplevert voor de medewerker zelf (zie Bassanini cs. (2007) voor een overzicht van deze studies). Andere studies die kijken naar de relatie tussen scholing en productiviteit baseren zich op de toegevoegde waarde die een bedrijfssector creëert (Dearden, Reed \& Van Reenen, 2006; Konings \& Vanormelingen, 2010). Deze studies geven aan dat het rendement van scholing op bedrijfsniveau circa twee keer zo hoog is als het effect op de lonen van de werknemers die de scholing hebben gevolgd. Daarbij blijft het echter de vraag of hier sprake is van een causale relatie tussen de trainingsdeelname en de productiviteitstoename.

Het gerandomiseerde veldexperiment van De Grip \& Sauermann (2012) laat zien dat er terdege sprake is van een substantieel causaal effect. Door het volgen van een training van een week die gericht was op het sneller kunnen begrijpen van de vraag die een klant heeft, bleek de productiviteit van callcenter medewerkers met maar liefst met $10 \%$ te stijgen. Daarbij werd de productiviteit gemeten door de zogenaamde Average Handling Time; een KPI die de productiviteit meet in termen van sneller werken. Dat laatste riep vanzelfsprekend de vraag op of deze productiviteitsstijging niet ten koste is gegaan van de kwaliteit van het geleverde werk. Dat bleek niet het 
geval te zijn. De tevredenheid van de klanten over de kundigheid van de medewerker die hen hielp nam zelfs toe en klanten hoefden niet vaker opnieuw te bellen omdat hun probleem niet was opgelost.

Ook het informele leren op het werk blijkt de productiviteit te verhogen. Dit komt vooral naar voren in studies die kijken hoe snel de productiviteit van nieuw aangetrokken medewerkers zich ontwikkelt. Verschillende studies laten zien dat er zeker in het eerste jaar dat iemand ergens werkt sprake is van een zeer snelle leercurve. Zo blijkt uit een studie van Shaw and Lazear (2008) dat de productiviteit van mensen die autovoorruiten plaatsen na een jaar werken maar liefst $82 \%$ hoger ligt dan toen men in de baan begon. Zo'n sterke leercurve bleek ook uit ons onderzoek onder nieuw aangestelde callcenter medewerkers. Deze waren na een jaar werken $64 \%$ productiever dan toen ze in hun baan starten (De Grip cs., 2016).

Zoals gezegd wordt het informele leren op het werk sterk gestimuleerd door technologische vernieuwingen van het productieproces (Fouarge cs., 2018). Dit betekent ook dat het informele leren zelf een een belangrijk positief spill-over effect is van investeringen in technologische vernieuwing, wat het rendement van investeringen in nieuwe technologie vergroot. Immers, door learning-by-doing met nieuwe apparatuur of software worden medewerkers steeds beter in het gebruik ervan en komen ze op ideeën voor verdere productiviteitsverhogende vernieuwingen. Interessant is dat deze ervaringskennis ook wordt overgebracht op andere bedrijven in de sector (Argote and Epple (1990). Dit geldt vooral voor opkomende hightech sectoren (Zimmerman, 1982) en wijst er 
op hoe belangrijk het voor een land kan zijn om in een vroeg stadium te investeren in bijvoorbeeld de energietransitie, elektrische auto's of kunstmatige intelligentie.

\section{Hoe effectief is het LLO voor de duurzame inzetbaarheid van werkenden?}

Vanwege de snelle technologische ontwikkelingen in combinatie met het naar achteren schuiven van de leeftijd waarop we met pensioen gaan, is er steeds meer aandacht gekomen voor de duurzame inzetbaarheid van werkenden. Binnen de duurzame inzetbaarheidsliteratuur en de hieraan nauw verwante employability literatuur is er min of meer een tweedeling tussen enerzijds de studies die zich richten op de vitaliteit van werkenden en anderzijds de studies die zich richten op de veroudering van kennis en vaardigheden. Een tweedeling die alleen overwonnen kan worden door multidisciplinair onderzoek.

Zelf heb ik me bij de start van mijn leerstoel gericht op het onderzoek naar scholingsveroudering, waar destijds nog weinig economisch onderzoek naar werd gedaan. Samen met Jasper van Loo en Ken Mayhew heb ik in 2001 in Maastricht de conferentie The Economics of Skills Obsolescence georganiseerd, waarvan een aantal papers in een gelijknamig boek in de Research in Labor Economics serie zijn gepubliceerd (De Grip cs., 2002). Daarin hebben we een review studie gepubliceerd (De Grip en Van Loo, 2002), waarin we een typologie hebben ontwikkeld van de verschillende mogelijke oorzaken van scholingsveroudering. Daarbij maken we - zoals 
standaard bij kapitaalgoederen gebeurt - een onderscheid tussen technische en economische veroudering. Bij technische scholingsveroudering gaat het om slijtage als gevolg van het natuurlijk ouderwordingsproces, letsel of ziekte of het onvoldoende gebruiken van eerder verworven kennis en vaardigheden. Dat wil zeggen: je kunt niet meer wat je vroeger wel kon. Bij economische scholingsveroudering gaat het daarentegen om de veroudering van kennis en vaardigheden vanwege technologische of organisatorische vernieuwingen of een krimpende werkgelegenheid in iemands vakgebied. Dat wil zeggen: je kunt het nog steeds, maar er is geen vraag meer naar.

In mijn artikel met Dennis Görlich (Görlich en De Grip, 2009) hebben we in navolging van Mincer en Ofek (1982) laten zien dat loopbaanonderbrekingen negatieve gevolgen hebben voor iemands salaris na herintrede op de arbeidsmarkt. Dit is zowel het geval na een periode van werkloosheid als na een periode waarin iemand thuis voor opgroeiende kinderen heeft gezorgd. Dit effect is het grootst bij hoger opgeleiden, maar is lager in beroepen waarin veel vrouwen werkzaam zijn. McDowell (1982) heeft laten zien dat in deze beroepen de scholingsveroudering vanwege technologische ontwikkelingen langzamer gaat dan in andere beroepen, wat een verklaring kan zijn voor de arbeidsmarktsegregatie tussen mannen- en vrouwenberoepen wanneer de arbeidsmarktparticipatie van vrouwen onderbrekingen kent vanwege zorgtaken. 
Maar het gevoel dat je kennis en vaardigheden verouderen betekent niet dat je een groter risico loopt om de arbeidsmarkt voortijdig te moeten verlaten. In mijn artikel met Jim Allen (Allen en De Grip, 2012) laten we zien dat werkenden die kampen met scholingsveroudering, vanwege de snelle ontwikkelingen in hun werk een functie hebben waarin ze veel kunnen leren. Bovendien moeten ze veel meer scholing volgen om up-to-date te blijven. Daardoor hebben werkenden die aangeven dat ze kampen met scholingsveroudering opmerkelijk genoeg een kleinere kans op baanverlies dan werkenden die in een minder dynamische functie werkzaam zijn.

Wat op dit punt erg belangrijk is, is dat werkgevers hun werknemers in staat stellen om scholing te volgen als dat belangrijk is voor hun baanbehoud. Zo laten De Grip, Fouarge, Montizaan en Schreurs (2020) zien dat niet alleen de deelname aan trainingen ertoe leidt dat mensen op latere leeftijd met pensioen willen gaan, maar ook louter het feit dat ze weten dat hun werkgever hen scholingsmogelijkheden aanbiedt als ze dat nodig zouden hebben voor hun duurzame inzetbaarheid.

In mijn interfacultaire samenwerking met de onderzoeksgroepen van mijn UM collega's IJmert Kant (FHML) en Fred Zijlstra (FPN) hebben we verschillende onderzoeken gedaan, waarin we scholingsveroudering plaatsen in het bredere kader van de duurzame inzetbaarheid van werkenden, waarin ook de fysieke en mentale belasting van het werk dat iemand doet een belangrijke rol spelen (zie Fleuren cs., 2018). In een schoolvoorbeeld van een multidisciplinair onderzoek hebben we zelfs gevonden dat er een duidelijke relatie is tussen 
scholingsveroudering en de gezondheid van werkenden. Uit dit onderzoek (Gommans cs., 2017) blijkt dat 45-plussers die kampen met tekortschietende competenties twee jaar later een grotere herstelbehoefte hebben aan het einde van hun werkdag en daardoor een groter risico lopen om hun baan te verliezen. Dit verbindt de duurzame inzetbaarheidsliteratuur gericht op de veroudering van kennis en vaardigheden met de literatuur gericht op de vitaliteit van werkenden.

\section{Voor welke groepen is het moeilijk om in de toenemende noodzaak van een leven lang ontwikkelen te voorzien?}

In het begin van mijn rede wees ik op de toenemende noodzaak tot LLO vanwege verschuivingen in de op de arbeidsmarkt gevraagde competenties als gevolg van de snelle technologische ontwikkelingen en de deels daarmee samenhangende veranderingen in het productieproces in vrijwel alle sectoren van de samenleving, in combinatie met het verlengen van de arbeidsloopbaan door het naar achteren schuiven van de pensioengerechtigde leeftijd. Dit roept de vraag op of het de Nederlandse beroepsbevolking lukt om hier goed op in te kunnen spelen door het volgen van trainingen en cursussen en het informele leren op het werk of daarbuiten.

Als we kijken naar de scholingsdeelname van werkenden dan zien we dat ruim de helft van de werkenden eens in de twee jaar minstens één training of cursus volgt (zie Figuur 1). Ook blijkt dat werkenden gemiddeld genomen een substantieel deel van hun werktijd activiteiten verrichten waarvan zij leren 
(Zie Figuur 2). Het glas is wat dat betreft halfvol, maar dat betekent helaas ook dat het halfleeg is. Zo blijkt dat een flinke groep werkenden na het verlaten van de schoolbanken nooit meer een training of cursus heeft gevolgd. Maar liefst ruim een kwart van de werkenden behoort tot deze harde kern van mensen die een groot risico lopen om later in hun loopbaan hun baan te verliezen en dan weinig kans te maken op ander werk (De Grip cs., 2018). Vaak gaat het hier om laagopgeleiden. Ik zal hier zo dadelijk verder op ingaan.

\section{Wie zijn op dit punt het meest kwetsbaar?}

Uit het ROA-LLL onderzoek blijkt dat drie groepen werkenden het meest kwetsbaar zijn in het up-to-date houden van hun menselijk kapitaal: lager opgeleiden, oudere werkenden en flexwerkers. Daarnaast zijn mensen die omgeschoold moeten worden naar ander werk vaak zeer kwetsbaar. Ik zal kort op deze vier groepen ingaan.

\section{Laagopgeleiden}

Figuur 5 laat zien dat laagopgeleiden veel minder vaak scholing volgen dan hoogopgeleiden. Vanaf 2010 is de kloof in de scholingsdeelname tussen laag- en hoogopgeleiden sterk gegroeid. Van de hoogopgeleiden nam in 2020 59\% deel aan een cursus of training tegenover slechts 33\% van de laagopgeleiden. Ook het verschil tussen de laag- en middelbaar opgeleiden is de afgelopen jaren gegroeid. In 2010 lag de scholingsdeelname van laag- en middelbaar opgeleiden nog vrijwel op hetzelfde niveau, maar vanaf 2013 daalde de scholingsdeelname van laagopgeleiden met ongeveer 10 procentpunt, terwijl de scholingsdeelname onder middelbaar opgeleiden met 6 procentpunt steeg. 
Figuur 5: Formeel leren: ontwikkeling van deelname aan cursussen en trainingen door werkenden naar opleidingsniveau, 2004-2020

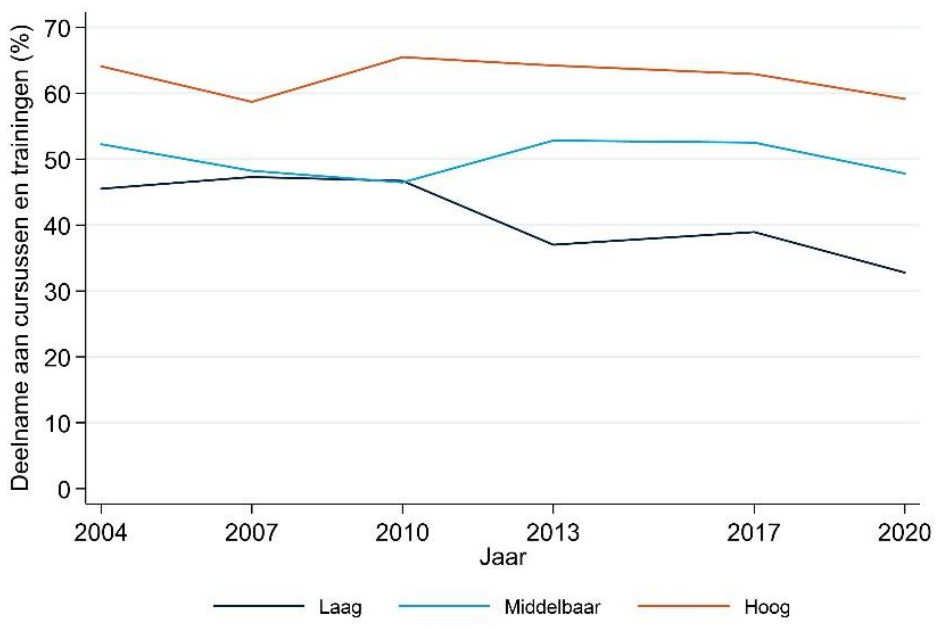

Bron: ROA LLL enquête, 2004-2020

De studie van Künn-Nelen cs. (2018) laat zien dat het verschil in scholingsparticipatie tussen laag- en hoogopgeleiden voor een belangrijk deel samenhangt met de verschillen in werkinhoud. De werkinhoud verklaart ook de verschillen tussen lager opgeleiden onderling. Als deze werken in een functie waarvoor interpersoonlijke vaardigheden en taalvaardigheden belangrijk zijn, dan volgen ze vaker scholing. Dat doen ze ook als ze meer feedback krijgen van hun collega's, of als ze een opleidings- of ontwikkelplan hebben. Laagopgeleiden nemen echter minder vaak zelf het initiatief om aan een training deel te nemen dan hoogopgeleiden.

Ook in Fouarge, Schils \& De Grip (2013) hebben we gekeken naar de redenen van de lage scholingsparticipatie van laag- 
opgeleiden. Het blijkt dat dit niet komt omdat het volgen van scholing door laagopgeleiden minder rendabel is. Gecontroleerd voor niet-waargenomen heterogeniteit blijken laagopgeleiden die de voorgaande twee jaar scholing hebben gevolgd 2,6\% meer te verdienen dan degenen die geen scholing hebben gevolgd. Dit rendement is vergelijkbaar met dat van hoger opgeleiden. Bovendien verlaagt het volgen van scholing voor laagopgeleiden het risico om werkloos te worden. Het onderzoek laat zien dat de lagere scholingsdeelname van lager opgeleiden hele andere oorzaken heeft. Zo blijkt dat examenangst een belangrijke reden is waarom lager opgeleiden minder scholing volgen. Ook blijkt dat laagopgeleiden minder toekomstgericht denken, meer waarde hechten aan hun vrije tijd, minder open staan voor nieuwe ervaringen ("openness") en minder het gevoel hebben dat ze invloed kunnen hebben op hun economisch welbevinden ("economic locus of control") dan hoger opgeleiden.

Laagopgeleiden blijken ook minder te leren van hun werk. Figuur 6 laat zien dat ze tijdens hun werk veel minder tijd besteden aan activiteiten waarvan ze kunnen leren dan hoogopgeleiden. Terwijl hoogopgeleiden in 2020 25\% van hun totale werktijd werkzaamheden hadden waarvan ze leren, was dit bij laagopgeleiden slechts $17 \%$ van hun werktijd. Middelbaar opgeleiden zitten daar tussenin. Zij besteden $22 \%$ van hun werktijd aan leerzame activiteiten. Overigens blijkt het informele leren bij middelbaar opgeleiden in (het coronajaar) 2020 op hetzelfde niveau te zijn gebleven, terwijl zowel bij laagals hoogopgeleiden het percentage dat ze aan leerzame activiteiten besteedden afnam. 
De verschillen in het informele leren tussen laag- en hoogopgeleiden hebben een aantal oorzaken (Künn-Nelen cs., 2018). Allereerst de minder leerzame inhoud van het werk van laagopgeleiden, maar ook omdat laagopgeleiden minder vaak een vast contract hebben en gemiddeld ouder zijn. Bovendien leren laagopgeleiden minder op hun werk omdat ze minder bevlogen zijn, minder bereid om risico te nemen en minder openstaan voor nieuwe ervaringen dan hoogopgeleiden.

Figuur 6: Informeel leren op het werk: ontwikkeling van het percentage van de werktijd besteed aan activiteiten waarvan men kan leren naar opleidingsniveau, 2004-2020

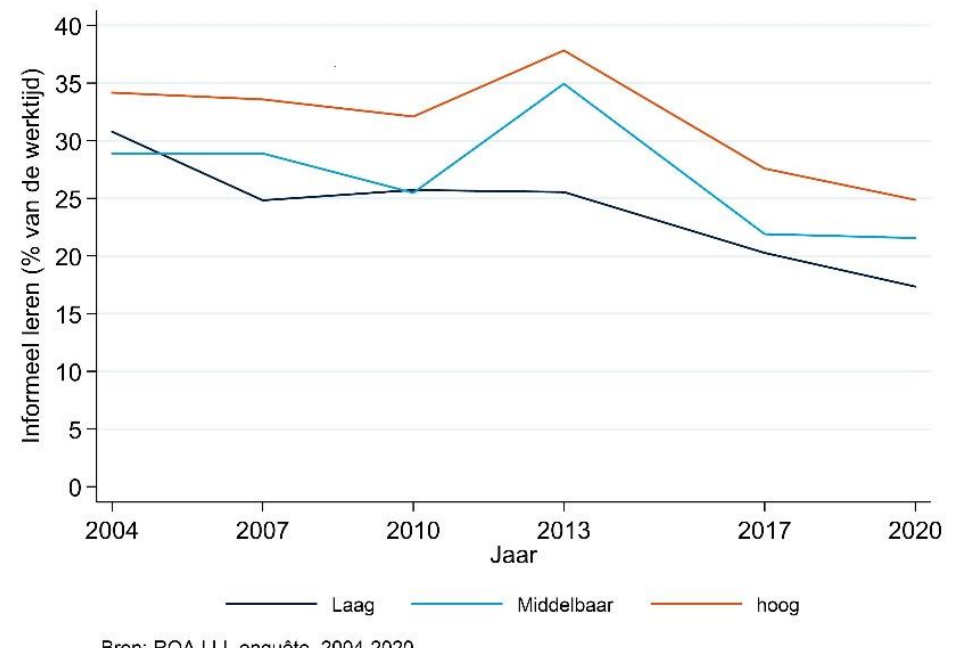

Bron: ROA LLL enquête, 2004-2020 


\section{Oudere werkenden}

Figuur 7 laat zien dat de scholingsdeelname het hoogst is onder de 30-40 jarigen. De scholingsparticipatie neemt vooral af in de laatste 10 jaar van de arbeidsloopbaan. Doordat de pensioenleeftijd steeds verder naar achteren is geschoven, is de scholingsparticipatie van oudere werkenden wel toegenomen. Hierdoor zijn de verschillen met andere leeftijdsgroepen steeds kleiner geworden, al laten de cijfers voor 2020 zien dat de scholingsdeelname van 55-plussers weer aan het teruglopen is.

Figuur 7: Formeel leren: ontwikkeling van deelname aan cursussen en trainingen door werkenden naar leeftijd, 2004-2020

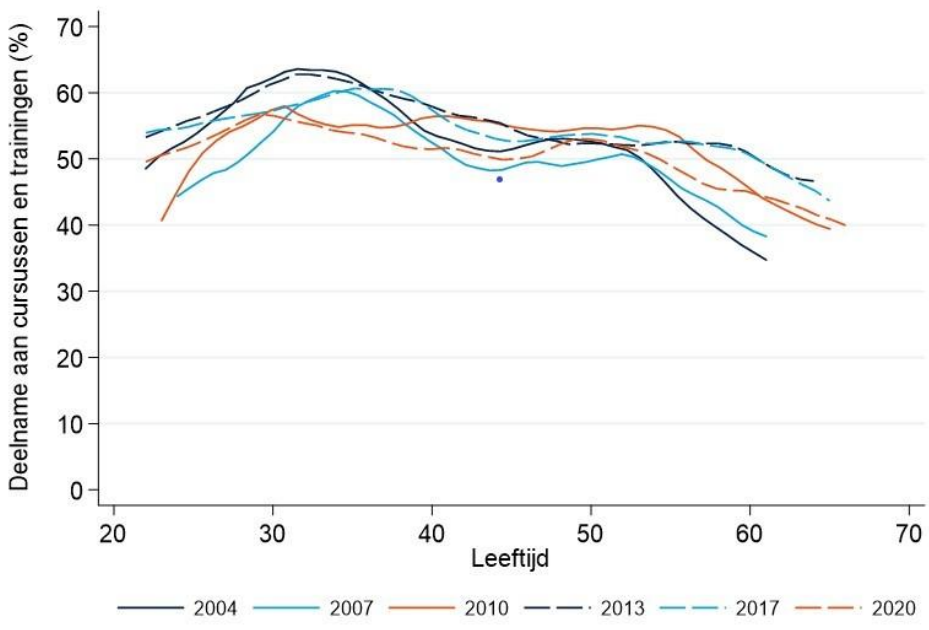

Bron: ROA LLL enquête, 2004-2020

Op basis van een natuurlijk experiment in de pensioengerechtigde leeftijd, Iaten Montizaan, Cörvers \& De Grip (2010) zien dat 55-jarigen die pas op latere leeftijd met pensioen 
kunnen gaan meer scholing volgen dan degenen die eerder met pensioen kunnen gaan. Dat geldt echter alleen voor degenen die in een grote organisatie werkzaam zijn, waar meestal meer aandacht is voor een goed HR-beleid dan in kleinere bedrijven.

De lagere trainingsdeelname van 55-plussers is vooral het gevolg van hun lagere bereidheid om een training te volgen, maar ook werkgevers zijn minder bereid om te investeren in de scholing van werknemers die ouder zijn dan 60-jaar. Vooral omdat werkgevers de leermotivatie en het leervermogen van oudere medewerkers lager inschatten (Künn-Nelen cs., 2018).

Oudere werkenden blijken ook minder te leren van hun werk. Uit Figuur 8 blijkt dat dit niet met het naderen van de pensioneringsleeftijd te maken heeft. Er is sprake van een vrij geleidelijke daling met het oplopen van de leeftijd. De figuur laat ook zien dat op alle leeftijdsniveaus het informele leren op het werk is afgenomen ten opzichte van 2004. Daarbij lijkt het later met pensioen gaan geen effect te hebben gehad op de mate waarin 55-plussers werkzaamheden hebben waarvan ze nog steeds leren. Dit - zoals we hiervoor zagen - in tegenstelling tot hun toegenomen scholingsparticipatie (zie Figuur $7)$. 
Figuur 8: Informeel leren op het werk: ontwikkeling van het percentage van de werktijd besteed aan activiteiten waarvan men kan leren naar leeftijd, 2004-2020

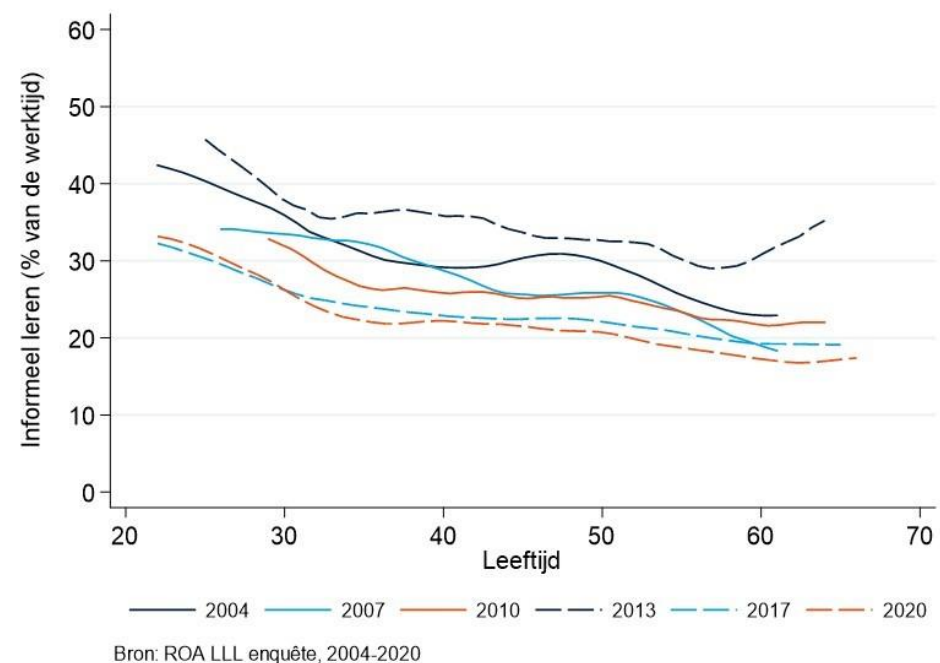

Uit de studie van Künn-Nelen cs. (2018) blijkt dat 55-plussers meer informeel leren op hun werk als hun werkzaamheden interpersoonlijke vaardigheden vereisen. Functieroulatie blijkt het informeel leren voor deze leeftijdsgroep niet meer te stimuleren. Integendeel, het leidt zelfs tot een afname van het informele leren. Mogelijk komt dit omdat functieroulatie op deze leeftijd vaak een onderdeel is van het ontziebeleid, waarbij oudere werkenden minder veeleisende taken krijgen.

\section{Flexwerkers}

Flexwerkers zijn in veel opzichten een kwetsbare groep op de arbeidsmarkt. Figuur 9 laat zien dat werkenden met een tijdelijk contract zonder perspectief op een vaste aanstelling 
veel minder vaak een training of cursus volgen dan werkenden met een vast contract. Terwijl van de werkenden met een vaste aanstelling de afgelopen twee jaar 53\% een cursus of training heeft gevolgd, is dit onder deze flexwerkers slechts $37 \%$. Ook onder zelfstandigen is de scholingsdeelname flink lager (43\%). Dat geldt in iets mindere mate voor werkenden met een tijdelijk contract die wel uitzicht hebben op een vaste aanstelling (45\%).

Figuur 9: Scholingsdeelname naar contracttype, 2020 (\%)

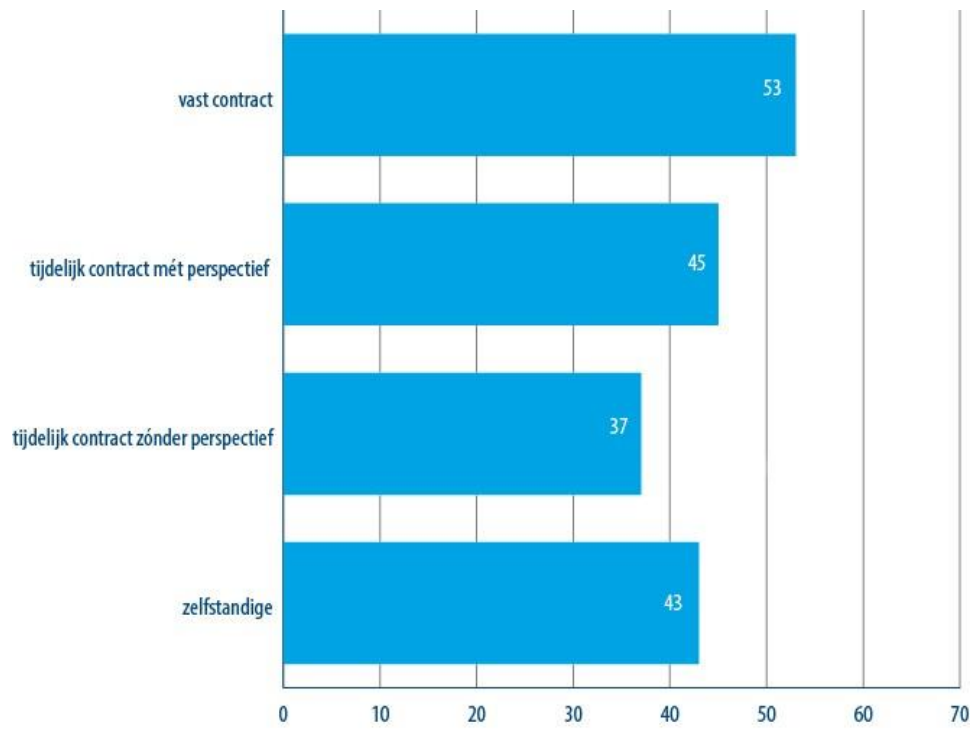

Ook moeten werknemers met een tijdelijk contract zonder uitzicht op een vaste aanstelling vaak zelf het initiatief nemen om scholing te kunnen volgen. Bovendien betalen ze veel vaker zelf de trainingskosten dan werknemers met een vaste baan en 
volgen ze de trainingen vaker in hun vrije tijd (Künn-Nelen cs., 2018).

Fouarge cs. (2012) laten zien dat flexwerkers vooral minder vaak trainingen volgen die bedoeld zijn om hun competenties up-to-date te houden dan werkenden met een vast contract. De trainingen die ze op eigen initiatief volgen zijn vaak gericht op generieke kennis en vaardigheden en helpen flexwerkers niet om een vaste baan te vinden.

Een vignetstudie van Poulissen, Fouarge, De Grip \& Künn-Nelen (2021) onder werkgevers laat zien dat werknemers met een tijdelijk contract zonder uitzicht op een vaste aanstelling maar liefst 37 procentpunt minder kans hebben een cursus aangeboden te krijgen van hun werkgever dan werknemers met een vast contract. Een terugbetalingsverplichting van de gemaakte scholingskosten bij vroegtijdig vertrek of een eigen financiële bijdrage van de werknemer verhogen weliswaar de kans dat werkgevers flexwerkers zonder uitzicht op een vaste aanstelling scholing aanbieden, maar zelfs dan hebben deze een veel lagere kans dat ze een cursus of training mogen volgen dan medewerkers met een vast contract of een tijdelijk contract met uitzicht op een vaste aanstelling.

Bij het informele leren op het werk zien we een heel ander beeld. Op dit punt blijven flexwerkers niet achter bij werkenden met een vast contract. Integendeel, zoals Figuur 10 laat zien, besteden ze een groter deel van hun werktijd aan activiteiten waarvan ze leren dan werknemers met een vast contract. Werkenden met een tijdelijk contract met perspectief op een vast dienstverband blijken $30 \%$ van hun werktijd te 
leren van het werk dat ze doen. Flexwerkers zonder perspectief op vast werk blijven daar met $28 \%$ nauwelijks bij achter. Dat is veel meer dan zelfstandigen, die $22 \%$ van hun werktijd leren van hun werkzaamheden. Dat is vrijwel evenveel als werkenden met een vast dienstverband, die slechts $21 \%$ van hun werktijd leren van het werk dat ze doen.

Figuur 10: Informeel leren in procenten van de werktijd naar contracttype, $2020(\%)$

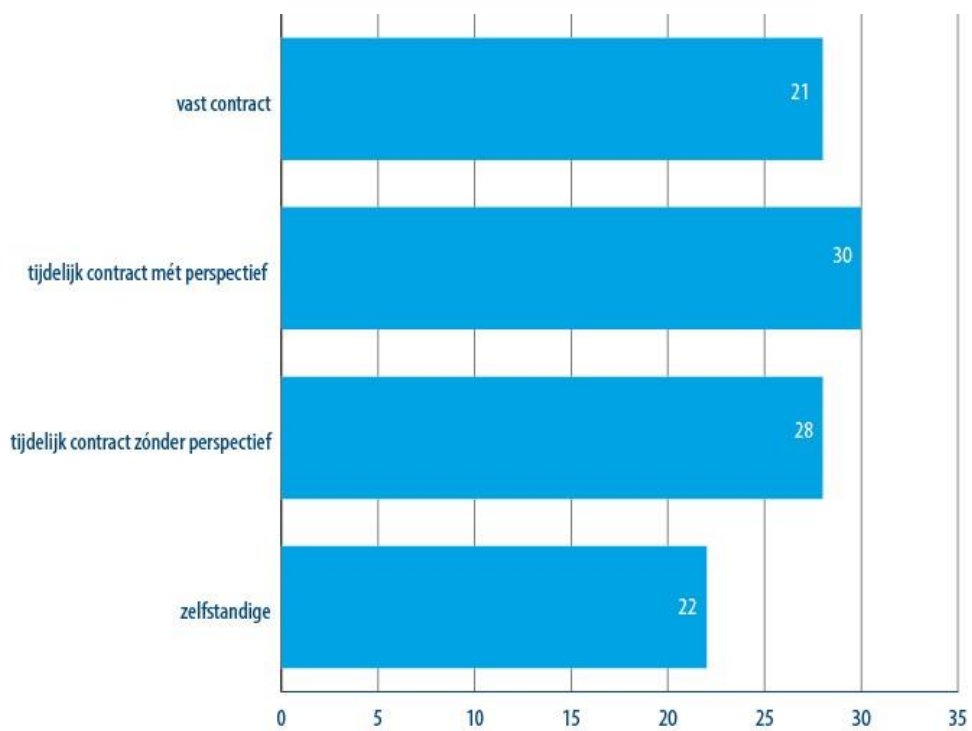

Ferreira, De Grip \& Van der Velden (2018) bevestigen dit beeld voor 20 OECD landen op basis van de PIAAC enquête. Uit deze studie blijkt dat het informeel leren geen substituut is voor de lagere trainingsparticipatie van flexwerkers. Integendeel: flexwerkers die training volgen leren ook meer van hun werk. 
Een aanvullende analyse die zich richt op de taken die werkenden uitvoeren wijst erop dat er twee soorten banen zijn waarin flexwerkers werkzaam zijn:

- goede tijdelijke banen met veel autonomie, teamwork en probleemoplossende taken, die goede mogelijkheden bieden voor het volgen van training en informeel leren en goede loopbaanperspectieven bieden;

- slechte tijdelijke banen, die weinig mogelijkheden bieden om je human capital op peil te houden en geen loopbaanperspectieven bieden.

\section{Langdurig werklozen en arbeidsongeschikten}

Naast de groepen werkenden die er onvoldoende in slagen om hun competenties op peil te houden om ook op termijn voldoende productief te zijn in hun huidige functie, is er een vierde kwetsbare groep: Dit zijn de mensen die op latere leeftijd hun baan verliezen, of hun werk fysiek of mentaal niet meer aankunnen, waardoor ze op zoek moeten naar ander werk. Vaak is er dan behoefte aan omscholing. Daarbij is het de vraag hoe die omscholing bekostigd kan worden. Het beste is als deze omscholing in een outplacementtraject nog door de oude werkgever wordt bekostigd, maar velen zijn aangewezen op door het UWV bekostigde omscholing. In een tweetal metaanalyses laten Card cs. $(2010 ; 2018)$ zien dat scholing van werklozen op de middellange termijn een positief effect heeft. Vaak vindt de scholing echter pas plaats als mensen langere tijd werkloos zijn. In dat geval is de inzetbaarheid van iemand vaak al sterk gedaald, wat het moeilijk maakt om nieuw werk te vinden (zie ook Van Landeghem, Cörvers \& De Grip (2017). Dit is ook het geval bij mensen die hun werk door de fysieke of 
mentale belasting ervan op een bepaald moment niet meer aankunnen. Vaak wordt er in dat geval gesproken van arbeidsongeschikten, maar deze ongeschiktheid heeft meestal vooral betrekking op het werk dat iemand had. Omscholing naar minder belastend werk zou dan in principe soelaas kunnen bieden, maar helaas zijn veel mensen die hun werk verliezen omdat ze het fysiek of mentaal niet meer aankunnen op een leeftijd waarop een succesvolle omscholing niet meer rendabel is, omdat de tijd waarin men de scholing op de arbeidsmarkt kan inzetten te kort is geworden (De Grip \& Montizaan, 2022).

\section{Welke maatschappelijk infrastructuur op het terrein van het LLO heeft onze samenleving nodig om een sterke economie te blijven?}

Nederland mist nog steeds een goede infrastructuur die een kennissamenleving nodig heeft om het menselijk kapitaal van de beroepsbevolking na het initieel onderwijs op peil en up-todate te houden. Hierdoor lopen we het risico dat de internationale concurrentiekracht en het innovatiepotentieel van de Nederlandse economie wordt aangetast. Een goede infrastructuur zou het LLO moeten borgen voor wat betreft het informeel leren op het werk, het bijscholen en opscholen en wanneer dat nodig is en het tijdig omscholen van mensen die geen perspectief meer hebben om in hun huidige werkveld te kunnen blijven werken.

In ons rapport Levenslang leren en competentieontwikkeling (De Grip cs., 2018) hebben we, mede op basis van een 
beleidsconferentie die we in 2018 samen met de SER hebben georganiseerd, aangegeven wat de contouren zouden moeten zijn van een goede maatschappelijke infrastructuur op het terrein van het LLO.

In verschillende adviezen heeft de SER de afgelopen jaren concrete voorstellen gedaan voor wat de pijlers van deze infrastructuur moeten zijn (SER, 2017, 2019, 2020) en ook aangegeven welke rol deze infrastructuur kan spelen voor het herstelbeleid dat nodig is om de Nederlandse samenleving na de coronacrisis weer te vitaliseren (SER, 2021). Deze adviezen bevatten tal van aanbevelingen voor het versterken van het LLO.

Ik wil hier ingaan op wat in mijn ogen vijf belangrijke pijlers zijn van een goede maatschappelijke infrastructuur op het terrein van het LLO:

- De leercultuur in organisaties en de samenleving

- Individuele ontwikkelrekeningen

- Alumnibeleid

- Faciliteiten voor omscholing

- Onderzoek

\section{Leercultuur in organisaties en samenleving}

Het informele leren op het werk vormt de basis van een goede leercultuur in een organisatie. Dat maakt het van groot belang dat medewerkers gedurende hun hele loopbaan taken hebben die hen voldoende uitdagen. Voorkomen moet worden dat mensen louter op basis van routine gaan werken en op den duur vastroesten in een takenpakket waarvan zij nog maar weinig leren. Dit vereist dat werkgevers hun medewerkers 
mogelijkheden tot functie- en taakroulatie aanbieden (De Grip \& Iske, 2012). Ook moet worden aangemoedigd dat medewerkers elkaar op de werkvloer feedback en tips geven. Daarbij moeten nieuwe medewerkers een mentor krijgen die hen de kneepjes van het vak leert. Gerards cs. (2021) laten zien dat het informele leren kan worden geborgd als medewerkers veel thuiswerken. Uit deze studie naar de relatie tussen 'het nieuwe werken' en het informele leren blijkt dat vooral het geven van kritische feedback bij het nieuwe werken een belangrijke rol speelt voor het informele leren op het werk. Daarnaast is het van groot belang dat medewerkers goede online toegang hebben tot de binnen de organisatie beschikbare kennis. Dit ondersteunt hen tijdens het werk bij het leveren van prestaties (Gottfredson \& Mosher, 2011).

Een goede leercultuur vereist ook een veilige leeromgeving. Medewerkers moeten fouten durven en mogen maken en niet aarzelen om aan collega's vragen te stellen als men iets niet weet. Ook moeten alle medewerkers regelmatig een opleidings- en ontwikkelgesprek hebben met hun leidinggevende, waarin hun loopbaanambities en -perspectieven en de hiervoor eventueel vereiste verandering van iemands takenpakket of bij- of omscholing worden besproken.

Belangrijk is ook dat de leercultuur van een organisatie inclusief is, door voldoende aandacht te hebben voor de werkenden die dreigen achter te blijven in het op peil houden van hun menselijk kapitaal. Daarbij gaat het zoals gezegd in het bijzonder om laagopgeleiden, oudere werkenden en flexwerkers. Vooral de harde kern van ruim een kwart van de werkenden die in hun hele arbeidsloopbaan nog nooit een 
training of cursus hebben gevolgd zal in de leercultuur moeten worden meegenomen. Dit vereist dat de barrières die deze groep heeft om te blijven leren worden weggenomen. Daarbij kan het bijvoorbeeld helpen om trainingen voor laagopgeleiden binnen een bedrijf in groepsverband te organiseren. Dan voelen medewerkers zich immers vaak verantwoordelijk voor collega's waarvoor de training moeilijk is. Ook zal geprobeerd moeten worden om laagopgeleiden zoveel mogelijk in kleinere modules praktijkgericht op de werkplek te laten leren, gerelateerd aan de taken die concreet uitgevoerd moeten worden. Daarnaast kunnen laagopgeleiden die eerder succesvol een training hebben gevolgd als leerambassadeurs hun collega's over de drempel trekken om zich verder te ontwikkelen. En last but not least zullen leidinggevenden op het terrein van LLO een vertrouwensband moeten creëren met hun medewerkers. Dit maakt de gesprekken hierover veel effectiever. Door medewerkers goed te informeren en te betrekken bij de grote veranderingen die zich in de economie voltrekken - en waaraan zowel bedrijven als hun medewerkers zich zullen moeten aanpassen - kunnen bedrijven ervoor zorgen dat hun medewerkers zich meer bewust worden van de noodzaak en de mogelijkheden om zich te blijven ontwikkelen.

In veel organisaties worden er al belangrijke stappen gezet om een betere leercultuur van de grond te krijgen, maar het is goed om te beseffen dat het HR-beleid op dit terrein vrijwel overal nog in de kinderschoenen staat. Dit maakt het ook voor de Nederlandse samenleving als geheel van groot belang om de leercultuur te versterken. Naast rol die er is weggelegd voor de overheid en het onderwijs, kunnen ook brancheorganisaties 
en opleidingsfondsen een belangrijke rol vervullen bij het versterken van de leercultuur in het midden- en kleinbedrijf in hun sector (De Grip cs., 2018).

De Nederlandse overheid heeft aangegeven de komende jaren te willen investeren in het verbeteren van de leercultuur in ons land. Om het inzicht in de scholingsmogelijkheden en mogelijke financieringsbronnen voor iedereen te vergroten, wil de overheid het digitaal scholingsplatform IKwilverderleren.nI ontwikkelen (De Vries, 2019). Daarnaast werkt de overheid aan het opzetten van een pilot met ontwikkeladviezen en ondersteuning voor praktisch geschoolde werkenden en werkzoekenden met een kwetsbare arbeidsmarktpositie. Deze pilot zal waarschijnlijk vanuit het Nationaal Groeifonds worden bekostigd (Commissie Nationaal Groeifonds, 2021). Ook wil de overheid in 2022 het zogenoemde 'STAP-budget' introduceren. Dat is een regeling voor een publiek leer- en ontwikkelbudget dat mensen de (financiële) mogelijkheid geeft hun duurzame inzetbaarheid te versterken. Dit STAP-budget zou een aanjaagfunctie kunnen vervullen voor het op bredere schaal introduceren van individuele ontwikkelrekeningen. Dit zijn goede initiatieven die de leercultuur in ons land kunnen versterken. Daarnaast kunnen de openbare bibliotheken nog meer dan ze nu al doen de leercultuur in onze samenleving versterken door het aanbieden van online-cursussen en trainingen voor een breed publiek. Ook kunnen bibliotheken door het aanbieden van taal-, reken- en digitaliseringscursussen en andere laagdrempelige activiteiten een waardevolle bijdrage leveren aan het stimuleren van de leercultuur van laaggeletterden en andere groepen die moeite hebben in 
hun leven te blijven leren. Hetzelfde geldt voor de publieke omroep die veel meer dan nu het geval is aandacht zou moeten hebben voor leerzame tv-programma's, podcasts, e.d. die toegankelijk zijn voor een brede doelgroep.

\section{Individuele ontwikkelrekeningen}

Individuele ontwikkelrekeningen kunnen een belangrijke gamechanger zijn voor het LLO in Nederland. Op zo'n ontwikkelrekening moeten werkenden fiscaal vriendelijk kunnen sparen voor ontwikkeltrajecten die belangrijk zijn voor hun duurzame inzetbaarheid op de arbeidsmarkt. De OECD (2019) geeft aan dat het belangrijk is dat er substantiële middelen op ontwikkelrekeningen komen te staan, omdat het anders alleen maar mogelijk is om af en toe een korte training te volgen die weinig invloed zal hebben op iemands employability. Daarom is het belangrijk dat zowel werkgevers, O\&O-fondsen, overheden als ook de werkende zelf geld kunnen storten op iemands ontwikkelrekening. Deze stortingen moeten daarom onderdeel worden van de in de C.A.O. vastgelegde arbeidsvoorwaarden. Daarvoor is het belangrijk dat de overheid de bedragen die werkgevers storten op de ontwikkelrekeningen van hun medewerkers niet fiscaal belast, zoals ook in het recente Brede Maatschappelijke Heroverwegingsrapport Ongekend talent van het Ministerie van Financiën wordt voorgesteld (inspectie der Rijksfinanciën, 2020).

Het zou goed zijn als iedereen zo'n ontwikkelrekening krijgt, omdat dit het mogelijk maakt om je eigen regie over de ontwikkeling van je kennis en vaardigheden te versterken. Juist voor de vier genoemde kwetsbare groepen kunnen Individuele 
ontwikkelrekeningen een belangrijke functie vervullen. Enerzijds omdat werkgevers hiermee kunnen worden aangezet om te investeren in de ontwikkeling van 55-plussers en de werkenden met een tijdelijk contract zonder uitzicht op een vaste aanstelling. Anderzijds omdat lager opgeleiden en 55plussers, die zelf minder geneigd zijn om een cursus te gaan volgen, door het endowment effect van een individuele ontwikkelrekening dit sneller zullen gaan doen. ${ }^{1}$ Dit betekent echter niet dat een individuele ontwikkelrekening voor de kwetsbare groepen die momenteel weinig scholing volgen vanzelf gaat werken. Om dat te bewerkstelligen is het creëren van een goede leercultuur langs de wegen die ik noemde cruciaal.

Een ontwikkelrekening is uitdrukkelijk niet bedoeld om de scholing te bekostigen die nodig is om iemands competenties voor de huidige functie up-to-date te houden. Daarvoor hoort de verantwoordelijkheid bij de werkgever te liggen. Deze heeft veel eerder een beter inzicht in de scholing die hiervoor nodig is. Maar los daarvan is het wenselijk dat een ontwikkelrekening ruime bestedingsmogelijkheden heeft (De Grip cs., 2018). Zo hebben werkenden met een tijdelijk contract zonder uitzicht op een vaste aanstelling vaak vooral behoefte aan loopbaanoriëntatie en coaching, terwijl voor laagopgeleiden het inwinnen van advies over de richting waarin men zich het beste kan ontwikkelen erg waardevol kan zijn. Het veldexperiment van Fleuren cs. (2018) laat zien dat het nuttig kan zijn als de middelen op de individuele ontwikkelrekening niet alleen kunnen worden ingezet voor het betalen van de cursuskosten, maar ook voor het vrijkopen van de werktijd 
waarin men de training kan volgen, omdat beide een belemmering om de scholing te gaan volgen kunnen wegnemen. Bij de kwetsbare groepen is het vrijkopen van werktijd waarschijnlijk vooral belangrijk om de scholingsdeelname van lager opgeleiden en 55-plussers te stimuleren.

Reeds in 2001 werd de principeafspraak tussen het kabinet en de Stichting van de Arbeid gemaakt om te komen tot een fiscale faciliteit voor leer- of ontwikkelrekeningen (SER, 2002). De afgelopen jaren hebben veel grote bedrijven dergelijke rekeningen ontwikkeld, of scholingsvouchers geïntroduceerd die hun medewerkers naar eigen inzicht in staat stellen scholing te volgen (Van Breugel, De Grip \& Dohmen, 2011). Het heeft allemaal lang geduurd, maar de afgelopen jaren heeft de SER met haar adviezen Leren en ontwikkelen tijdens de loopbaan (SER, 2017) en Private scholingsmiddelen (SER, 2020) en de Actie-agenda Leven Lang Ontwikkelen (SER, 2020b) een belangrijke aanjaagfunctie vervuld om Individuele ontwikkelrekeningen van de grond te krijgen.

Zoals gezegd wil de overheid volgend jaar het 'STAP-budget' introduceren. Het zou goed zijn als dit de opstap wordt naar het op bredere schaal introduceren van individuele ontwikkelrekeningen.

\section{Alumnibeleid}

Mbo-scholen, hogescholen en universiteiten zouden een veel grotere rol kunnen spelen bij het up-to-date houden van de competenties van hun alumni dan ze momenteel doen. Dit vereist een strategisch alumnibeleid, waarin het LLO centraal staat (De Grip cs., 2018). Daarbij gaat het zowel om het 
aanbieden van post-initiële scholing aan afgestudeerden als om het organiseren van netwerkactiviteiten, waarin alumni korte updates van hun kennis krijgen en ook veel van elkaar kunnen leren (De Grip \& Pleijers, 2019). Om dit alumnibeleid een impuls te geven zouden onderwijsinstellingen op flinke schaal online of blendid learning bijscholingscursussen voor hun alumni moeten gaan opzetten, voortbouwend op de ervaringen die zij hiermee de afgelopen anderhalf jaar hebben opgedaan. Belfi cs. (2018) laten zien dat werkloze alumni en alumni die zijn afgestudeerd in crisistijd de eerste jaren na hun afstuderen minder vaak een cursus of training volgen. Daarom zou er in het alumnibeleid van onderwijsinstellingen speciale aandacht moeten komen voor deze beide doelgroepen.

\section{Faciliteiten voor omscholing}

Het hebben van een goede leercultuur, individuele leerrekeningen en een goed alumnibeleid van kennisinstellingen vormen de maatschappelijke infrastructuur die nodig is voor wat je zou kunnen aanduiden als het preventieve LLO-beleid. Daarnaast is het echter soms nodig dat mensen die geen perspectief meer hebben om aan het werk te blijven in hun beroep of sector omgeschoold worden naar ander werk. De behoefte aan dit meer curatieve scholingsbeleid doet zich voor als mensen door verschuivingen in de vraag op de arbeidsmarkt hun baan verliezen en er vrijwel geen mogelijkheden meer zijn om een soortgelijke baan te vinden. Maar omscholing kan - zoals gezegd - ook nodig zijn als iemand werkzaam is in een fysiek of mentaal sterk belastend beroep en dit niet kan volhouden tot haar of zijn pensioengerechtigde leeftijd. In dat geval is het erg belangrijk dat deze omscholing 
niet pas wordt overwogen als mensen hun huidige werk niet meer aankunnen, maar dat hierop wordt geanticipeerd door hen om te scholen op een leeftijd van 40-45 jaar, waarop deze omscholing nog rendabel is. Dit onder het motto: preventief LLO-beleid waar mogelijk met curatief beleid als vangnet voor onvoorziene omstandigheden.

In haar advies Inventarisatie Leven Lang Ontwikkelen in de sociale zekerheid geeft de SER (2019) aan dat er bij de reintegratie van werklozen te weinig aandacht is voor een duurzame re-integratie als deze alleen bereikt kan worden door een substantiële scholingsinzet (Inspectie der Rijksfinanciën, 2020). Bovendien heeft het UWV onvoldoende mogelijkheden om dergelijke omscholing aan te bieden voordat iemand werkloos is geworden. ${ }^{2}$ Zoals gezegd, zal het omscholingsbeleid veel effectiever kunnen worden als het vroegtijdig plaatsvindt. Dit omdat dan de afstand tot de arbeidsmarkt nog kleiner is en omdat het nieuwe verworven menselijk kapitaal dan nog langer rendabel op de arbeidsmarkt kan worden ingezet.

\section{Onderzoek}

Een sterke onderzoekagenda vormt een cruciaal onderdeel van een goede maatschappelijke infrastructuur op het terrein van het LLO. Het onderzoek kan daarbij zowel agenderend zijn voor nieuwe beleidsinitiatieven als betrekkelijk snel laten zien wat de effectiviteit is van verschillende beleidsinitiatieven. Dit vereist drie soorten onderzoek: 
- Onderzoek dat inzicht geeft in de kennis en vaardigheden waaraan op de Nederlandse arbeidsmarkt behoefte is

De prognoses van de toekomstige vraag en aanbod op de arbeidsmarkt naar opleiding en beroep waarmee het ROA eind jaren ' 80 van de vorige eeuw is gestart, verschaffen essentiële informatie over de op de middellange termijn verwachte ontwikkelingen op de arbeidsmarkt naar beroep en opleiding (De Grip, Heijke \& Dekker, 1989; Bakens cs., 2019). In de loop van de jaren is gebleken dat de kwaliteit van deze prognoses zeer hoog is. Daarmee kunnen ze aangeven voor welke werkvelden minder of meer zou moeten worden opgeleid. Deze informatie is niet alleen zeer waardevol voor de studieen beroepskeuzevoorlichting en het wervingsbeleid van werkgevers, maar kan ook een belangrijk ankerpunt zijn voor een goed omscholingsbeleid.

Om meer specifiek inzicht te krijgen in de verschuivingen in de op de arbeidsmarkt gevraagde kennis en vaardigheden, is het belangrijk om naast deze arbeidsmarktprognoses naar beroep en opleiding goed te blijven monitoren welke verschuivingen er op de arbeidsmarkt tussen en binnen beroepen optreden in de werkzaamheden van de werkenden. Het in 2012 en 2017 in navolging van het British Skills Survey door ROA en SEO uitgevoerde Nederlandse Skills Survey biedt hiervoor goede mogelijkheden (Van den Berg cs., 2018). Voor een goed LLObeleid is het van groot belang dat het Ministerie van SZW dit Skills survey in de toekomst blijft bekostigen. 
- Onderzoek dat inzicht geeft in de ontwikkeling van het LLO in Nederland

Het goed blijven monitoren van de ontwikkelingen in de scholingsdeelname en het informele leren van de Nederlandse beroepsbevolking en de factoren die dit stimuleren of belemmeren is ook een cruciaal onderdeel van een goede maatschappelijke infrastructuur op het terrein van het LLO. In 2004 is het ROA - zoals ik in deze lezing heb laten zien - gestart met de ROA Leven Lang Leren enquête. Deze enquête heeft de afgelopen jaren onder andere een belangrijke bijdrage geleverd aan het maatschappelijk agenderen van het belang van het informele leren op het werk en ook de groepen werkenden die het risico lopen hun competenties onvoldoende op peil te houden scherp in beeld gebracht. Hoewel deze enquête sinds die tijd om de drie jaar is gehouden, is een meer duurzame bekostiging daarvan nog steeds onvoldoende geborgd. Ook hier ligt een duidelijke rol voor het Ministerie van SZW.

\section{- Onderzoek naar wat werkt en waarom}

Zowel binnen bedrijven als op sector- en regionaal niveau zijn er al tal van initiatieven gericht op het LLO. Veel van deze initiatieven hebben echter betrekking op pilots die niet zodanig zijn opgezet dat een goede effectmeting mogelijk is. Daardoor wordt er onvoldoende geleerd van deze pilotprojecten en dreigt het gevaar dat het wiel telkens opnieuw moet worden uitgevonden. Om dit te voorkomen is het van groot belang dat er reeds voor de start van een nieuw initiatief goed wordt nagedacht op welke wijze de interventie goed kan worden 
geëvalueerd. Hoewel dit niet altijd makkelijk is, zijn er goede voorbeelden hoe dit in de praktijk zou kunnen (De Grip \& Sauermann, 2012; Hidalgo cs., 2014; Fleuren cs., 2018). In De Grip, Künn \& Montizaan (2019) hebben we voor het Ministerie van SZW een raamwerk geschetst met vijf evaluatiemethodes om de effecten van LLO-initiatieven op een verantwoorde wijze te meten. Dit zou de leidraad moeten zijn voor een goed evaluatiekader voor het LLO-beleid

Goed opgezet onderzoek naar de effecten van interventies maakt het niet alleen mogelijk dat een goed beeld wordt verkregen van wat werkt. Het kan ook inzicht geven warom een bepaalde interventie effectief is en bij welke opzet het beste resultaat wordt bereikt (zie bv. Fleuren cs., 2018). Daarbij kan het zeer waardevol zijn om evaluatiestudies te relateren aan het monitoringsonderzoek, om op die manier een goede controlegroep te kunnen waarborgen (zie Schwerdt cs., 2012).

\section{Dankwoord}

Tot slot wil ik graag een dankwoord uitspreken aan degenen die het mij de afgelopen twee decennia mogelijk hebben gemaakt om invulling te geven aan het onderzoek en onderwijs gerelateerd aan mijn leerstoel en de doorgroei van het ROA tot een toonaangevend onderzoeksinstituut dat zich in haar missie richt op hoogwaardig wetenschappelijk onderzoek met maatschappelijke impact. Als eerste gaat mijn dank uit naar Hans Heijke, die destijds als directeur van het ROA het initiatief nam voor het opzetten van mijn leerstoel als tweede leerstoel binnen het ROA en mij daarmee de mogelijkheid bood om het 
ROA uit te bouwen met een nieuwe onderzoekslijn gericht op het postinitiële leren. Thomas Dohmen wil ik bedanken voor zijn belangrijke voorbeeldrol voor het doen van hoogwaardig maatschappelijk relevant wetenschappelijk onderzoek en zijn fijne leiderschapsstijl.

Zoals blijkt uit mijn vele co-auteurs hebben vele anderen binnen en buiten het ROA een belangrijke rol gespeeld voor het aan mijn leerstoel gerelateerde onderzoeksprogramma Scholing en Werk. Allereerst de promovendi die ik heb mogen begeleiden bij het schrijven van hun proefschrift. Ik heb dit altijd een van de leukste werkzaamheden van mijn leerstoel gevonden. Het is enorm mooi en dankbaar werk om meestal jonge onderzoekers in deze voor hen belangrijke fase in hun loopbaan feedback te kunnen geven op hun onderzoek en ook in bredere zin te kunnen coachen. Ook voor mezelf waren dit zeer leerzame activiteiten, waarvan ik ongetwijfeld meer leerde dan van het volgen van een cursus of training.

Met veel van mijn promovendi en vele andere collega's binnen en buiten het ROA heb ik aan wetenschappelijke papers gewerkt. Voor mij is wetenschap altijd teamwork geweest. Ik heb het even nageteld. In totaal heb ik met 81 co-auteurs gewerkt aan in internationale journals gepubliceerde wetenschappelijke artikelen. Van deze co-auteurs waren er 37 mijn collega's van het ROA, 38 collega's van buiten het ROA en 6 SBE Masterstudenten waarmee ik een artikel schreef op basis van hun Master thesis. Bedankt allemaal voor de fijne samenwerking en de vele dingen die ik op allerlei facetten van het schrijven van een goed artikel van jullie heb geleerd. 
Veel van mijn co-auteurs binnen en buiten het ROA hebben het voor mij mogelijk gemaakt om het LLO, duurzame inzetbaarheid en andere onderzoeksterreinen vanuit een interdisciplinair perspectief te bestuderen. Dit heeft mij in aanraking gebracht met het onderzoek alsook de onderzoekmores binnen disciplines als sociologie, onderwijskunde, neuropsychologie, organisatiepsychologie en arbeidsepidemiologie. Dit waren leerzame uitstapjes die mijn blik op de wetenschap enorm hebben verrijkt. Ik wil jullie allemaal bedanken voor de vele wijze lessen en de fijne samenwerking. Het lukt me helaas niet om al jullie namen hier te noemen, maar ik wil in het bijzonder IJmert Kant en Fred Zijlstra bedanken voor de leerzame samenwerking in verschillende samenwerkingsprojecten, die me een dieper inzicht hebben gegeven in het grote belang van multidisciplinair onderzoek op het terrein van de duurzame inzetbaarheid van werkenden.

Paul Iske wil ik bedanken voor de plezierige samenwerking bij de coördinatie van het Netwerk Sociale Innovatie en het inzicht dat hij me gegeven heeft in hoe belangrijk het is om fouten te mogen maken en om ervoor te zorgen dat een organisatie leert van de fouten die er worden gemaakt. Eveneens leerde ik van Paul om organisaties te zien als onderdeel van een groter ecosysteem. Hiervan heb ik ook geleerd het ROA te zien als een onderdeel van een groter ecosysteem, waarbij het niet zo belangrijk is om scherpe grenzen te trekken tussen wat er in dit ecosysteem binnen het ROA of daarbuiten plaatsvindt.

Naast deze wetenschappelijke publicaties heb ik met veel plezier met veel ROA collega's gewerkt aan soms spraakmakende rapporten, waarmee we een belangrijke agen- 
derende rol hebben kunnen spelen voor het beleid gericht op de relatie tussen onderwijs en arbeidsmarkt, het leven lang ontwikkelen, duurzame inzetbaarheid, het verschuiven van de pensioneringsleeftijd en de impact van het nieuwe werken en kunstmatige intelligentie op het werk. Ik kan helaas jullie hier niet allemaal bij naam noemen, maar ik wil op de onderzoeksen beleidsterreinen die ik net noemde vooral mijn ROA collega's Lex Borghans, Frank Cörvers, Didier Fouarge, Hans Heijke, Annemarie Künn-Nelen, Raymond Montizaan, Ruud Gerards, Marie-Christine Fregin en Mark Levels bedanken voor de fijne manier waarop we hebben samengewerkt in het besef dat we met iets grensverleggends bezig waren. Ik hoop de komende jaren de samenwerking met verschillende van jullie nog te kunnen voortzetten.

Erg belangrijk was de fijne ondersteuning die ik bij mijn werk altijd heb gehad van het ROA secretariaat en beheer. Miranda Boere, Mariëlle Retz, Esther Soudant, Joyce Gruijthuijsen, Melissa Llanes en Margo Romans, bedankt voor al jullie support.

Graag wil ik hier ook mijn collega Rolf van der Velden bedanken voor de enorm fijne samenwerking in de dertig jaar dat we samen binnen het ROA zijn opgetrokken en onze vriendschap die hiervoor de basis vormde. Legendarisch binnen het ROA zijn onze lunchwandelingen die we in deze 30 jaar met grote regelmaat samen maakten, waarin we elkaar feedback gaven, beslissingen namen en lief en leed deelden. De kroon op deze goede samenwerking was ons gedeelde directeurschap in de afgelopen 8 jaar, waarin het ROA is doorgegroeid tot een op vele terreinen toonaangevend onderzoeksinstituut. 
In de periode van ons gezamenlijke ROA-directeurschap zijn we erin geslaagd het ROA een volwaardige positie te geven binnen de School of Business and Economics (SBE), wat een belangrijke borging is voor het wetenschappelijk onderzoek binnen ROA en waarbij we met onze missie een rolmodel zijn voor het combineren van hoogwaardig wetenschappelijk onderzoek met een grote maatschappelijke impact. Mijn dank gaat uit naar de toenmalige SBE-decaan Philip Vergauwen en directeur Edward Peters die deze integratie mogelijk hebben gemaakt en Peter Møllgaard die de integratie een verdere boost gaf door me te vragen als Associate Dean plaats te nemen in het faculteitsbestuur.

Ik ben erg blij dat ik in mijn loopbaan een bijdrage heb kunnen leveren aan de opbouw en doorgroei van het ROA. Ik heb dit altijd met erg veel plezier gedaan en kan hier met veel genoegen op terugkijken. Maar ik ben minstens zo blij dat Marise en onze kinderen Mila, Feiko, Benno en Jos mij altijd gewaardeerd hebben voor mijn in hun ogen goede worklife balance. Ik wil jullie, jullie partners Rob, Thomas, Raphael en Livia en onze kleinkinderen Boas en Lovis bedanken voor jullie bijdrage aan het warme gezin dat we vormen en het vele dat ik nog steeds van jullie allemaal kan leren.

Ik heb gezegd. 


\section{Noten}

1 Dit endowment effect treedt op omdat we het belangrijker vinden dat iets wat we bezitten niet verloren gaat dan het mogelijk iets kunnen bezitten dat we nog niet bezitten (zie Kahneman \& Tversky (1979).

2 Gelukkig heeft het UWV eind 2020 wel de mogelijkheid gekregen om werkenden vier maanden voordat ze werkloos dreigen te worden naar ander passend werk te begeleiden. 


\section{Literatuur}

Jim Allen, Andries de Grip (2012). Does skill obsolescence increase the risk of employment loss? Applied Economics, 44, 3237-3245.

Linda Argote, Dennis Epple (1990). Learning Curves in Manufacturing, Science, 23, 920-924.

Jessie Bakens, Ineke Bijlsma, Sander Dijksman, Didier Fouarge, Griet de Lombaerde (2019). De arbeidsmarkt naar opleiding en beroep tot 2024. ROA-R-2019/7, Maastricht.

Andrea Bassanini, Alison Booth, Giorgio Brunello, Maria De Paola, Edwin Leuven (2007). Workplace training in Europe, in G. Brunello, P. Garibaldi and E. Wasmer, eds., Education and Training in Europe, pp. 143-289, Oxford: Oxford University Press.

Barbara Belfi, Jim Allen, Peter van Eldert, Andries de Grip, Annemarie Künn-Nelen, Tim Peeters, Davey Poulissen (2018). Schoolverlaters in crisistijd: Gevolgen voor leren en de vroege loopbaan, ROA-R-2018/7, Maastricht.

Emina van den Berg, Peter van Eldert, Didier Fouarge, Bas ter Weel (2018). Taken en vaardigheden op het werk. Bevindingen uit de eerste en tweede Nederlandse Skills survey. ROA-R-2018/6, Maastricht.

Lex Borghans, Bart Golsteyn en Andries de Grip (2006). Meer werken is meer leren, CINOP Expertisecentrum, 's-Hertogenbosch.

Lex Borghans, Bart Golsteyn, Andries de Grip (2007). Werkend leren, Economische Statistische Berichten, 92, 260-264

Lex Borghans, Didier Fouarge, Andries de Grip (2011). Een leven lang leren in Nederland, ROA-R-2011/5, Maastricht.

Lex Borghans, Didier Fouarge, Andries de Grip, Jesper van Thor (2014). Werken en leren in Nederland. ROA-R-2014/3, Maastricht, ROA.

Gerla van Breugel, Andries de Grip, Dieter Dohmen (2011). Ontwikkelingscheque, Uitwerking Advies Denktank Leren en Werken, ROA-R-2011/3, Maastricht.

David Card, Jochen Kluve, Andrea Weber (2010). Active Labour Market Policy Evaluations: A Meta-Analysis, The Economic Journal, 120, F452-F477.

David Card, Jochen Kluve, Andrea Weber, 2018. What Works? A Meta-Analysis of Recent Active Labor Market Program Evaluations, Journal of the European Economic Association, European Economic Association, 16, 894-931.

Commissie Nationaal Groeifonds (2021). Rapport eerste beoordelingsronde, Ministerie van Economische Zaken en Klimaat, Den Haag.

Thomas Cornelissen, Christian Dustmann, Ute Schoenberg (2017). Peer Effects in the Workplace. American Economic Review, 107, 425-456.

Lorraine Dearden, Howard Reed, John Van Reenen (2006). The impact of training on productivity and wages: evidence from British panel data, Oxford Bulletin of Economics and Statistics, 68, 397-421. 
Peter van Eldert, Didier Fouarge, Annemarie Künn-Nelen (2018). Cursusdeelname, inzetbaarheid en lonen, Tijdschrift voor Arbeidsvraagstukken, 34, 340- 354.

Michael Eraut (2004). Informal learning in the workplace. Studies in Continuing Education, 26, 247-273.

Maria Ferreira, Andries de Grip, Rolf van der Velden (2018). Does Informal Learning at Work Differ between Temporary and Permanent Workers? Evidence from 20 OECD Countries, Labour Economics, 55, 18-40.

Bram Fleuren, Ludovic van Amelsvoort, Fred Zijlstra, Andries de Grip \& IJmert Kant (2018). Handling the reflective-formative measurement conundrum: A practical illustration based on sustainable employability, Journal of Clinical Epidemiology, 103, 71-81.

Bram Fleuren, Andries de Grip, IJmert Kant \& Fred Zijlstra (2020). Time equals money? A randomized controlled field experiment on four types of training vouchers, Journal of Vocational Behavior, 118, 103403

Didier Fouarge, Peter van Eldert, Andries de Grip, Annemarie Künn-Nelen, Davey Poulissen (2018). Nederland in Leerstand, ROA-R-2018/4, Maastricht.

Didier Fouarge, Andries de Grip, Annemarie Nelen (2009), Leren en werken, ROA-R2009/3, Maastricht.

Didier Fouarge, Trudie Schils, Andries de Grip (2013). Why Do Low-Educated Workers Invest Less in Further Training? Applied Economics, 45, 2587-2601.

Didier Fouarge, Andries de Grip, Wendy Smits, Robert de Vries (2012). Flexible contracts and human capital investments, The Economist, 160, 177-195.

Ruud Gerards, Andries de Grip, Arnoud Weustink (2021). Do New Ways of Working increase informal learning at work? Personnel Review.

Con Gottfredson, Bob Mosher (2011). Innovative Performance Support: Strategies and Practices for Learning in the Workflow: Strategies and Practices for Learning in the Workflow, McGraw-Hill, New York.

Fleur Gommans, Nicole Jansen, Dave Stynen, IJmert Kant, Andries de Grip (2017). The effects of under-skilling on need for recovery, losing employment and retirement intentions among older office workers: A prospective cohort study, International Labour Review, 156, 525-548.

Dennis Görlich and Andries de Grip (2009). Human capital depreciation during hometime, Oxford Economic Papers, 61 i98-i121.

Andries de Grip (2015). The importance of informal learning at work, IZA World of Labor, Bonn.

Andries de Grip, Barbara Belfi, Didier Fouarge, Annemarie Künn-Nelen, Tim Peeters, Davey Poulissen (2018). Levenslang leren en competentieontwikkeling Beleidsrapport, ROA-R-2018/8, Maastricht.

Andries de Grip, Hans Heijke en Ron Dekker (1989). De arbeidsmarkt naar opleiding en beroep in 1992, ROA-R-1989/8, Maastricht. 
Andries de Grip, Didier Fouarge, Raymond Montizaan, Bert Schreurs (2020). Train to Retain: Training Opportunities, Positive Reciprocity, and Expected Retirement Age, Journal of Vocational Behavior 117, 1-15.

Andries de Grip, Paul Iske (2012). Taakroulatie in plaats van functieroulatie. Gids voor Personeelsmanagement, 91(7/8), 18-20.

Andries de Grip, Annemarie Künn, Raymond Montizaan (2019). Raamwerk Evaluatie Interventies Leven Lang Ontwikkelen. ROA-R-2019/7, Maastricht.

Andries de Grip, Raymond Montizaan (2022). Human capital investments and aging, in D.E. Bloom, A. Sousa-Poza and U. Sunde (Eds.), Routledge Handbook on the Economics of Ageing, London: Routledge.

Andries de Grip and Astrid Pleijers (2019). Workshop attendance as a mode of learning: evidence from the Netherlands, Vocations and Learning, 12, 361-385.

Andries de Grip, Jan Sauermann (2012). The effects of training on own and co-worker productivity: evidence from a field experiment The Economic Journal, 122, 376399.

Andries de Grip, Jan Sauermann, Inge Sieben (2016). The Role of Peers in Estimating Tenure-Performance Profiles: Evidence from Personnel Data, Journal of Economic Behavior \& Organization, 126, 39-54.

Andries de Grip, Jasper van Loo (2002). The Economics of Skills Obsolescence: A Review, in A. de Grip, J. van Loo and K. Mayhew (Eds.), The Economics of Skills Obsolescence, Research in Labor Economics, vol. 21, JAI Press, 1-26.

Andries de Grip, Jasper van Loo, Ken Mayhew (Eds.) (2002). The Economics of Skills Obsolescence, Research in Labor Economics, vol. 21, JAI Press.

Daniel Herbst, Alexandre Mas (2015). Peer effects on worker output in the laboratory generalize to the field, Science, 350, 545-549.

Diana Hidalgo, Hessel Oosterbeek, Dinand Webbing (2014). The impact of training vouchers on low-skilled workers. Labour Economics, 31, 117-128.

Daniel Kahneman, Amos Tversky. (1979). Prospect Theory: An analysis of Decision under Risk, Econometrica, 47, 263-292.

Inspectie der Rijksfinanciën (2020). Ongekend talent. Talenten benutten op de arbeidsmarkt, Brede maatschappelijke heroverweging, Ministerie van Financiën, Den haag.

Mark Killingsworth (1982). Learning by Doing" and "Investment in Training: A Synthesis of Two "Rival" Models of the Life Cycle, Review of Economic Studies, 49, 263-271.

Jozef Konings, Stijn Vanormelingen (2015). The impact of training on productivity and wages: firm level evidence, Review of Economics and Statistics, 97, 485-497.

Annemarie Künn-Nelen, Davey Poulissen, Peter van Eldert, Didier Fouarge, Andries de Grip (2018). Leren onder werkenden met een kwetsbare positie op de arbeidsmarkt, ROA-R-2018/5, Maastricht. 
Bert Van Landeghem, Frank Cörvers, Andries de Grip (2017). Is there a rationale to contact the unemployed right from the start? Evidence from a natural field experiment, Labour Economics, 45, 158-168.

John McDowell (1982). Obsolescence of Knowledge and Career Publication Profiles: Some Evidence of Differences among Fields in Costs of Interrupted Careers, American Economic Review, 72, 752-768.

Jacob Mincer (1974). Schooling, Experience and Earnings, National Bureau of Economic Research, New York.

Jacob Mincer, Haim Ofek (1982). Interrupted Work Careers: Depreciation and Restoration of Human Capital, Journal of Human Resources, 7, 3-24.

Raymond Montizaan, Frank Cörvers, Andries de Grip (2010). The effects of pension rights and retirement age on training participation: Evidence from a natural experiment, Labour Economics, 17, 240-247.

OECD (2019). Individual Learning Accounts: Panacea or Pandora's Box? OECD Publishing, Paris.

Davey Poulissen, Andries De Grip, Didier Fouarge, Annemarie Künn-Nelen (2021). Employers' willingness to invest in the training of temporary workers: a discrete choice experiment, ROA-RM-2021/3, Maastricht

SCP (2019). Grenzen aan een leven lang leren, Den Haag.

Eva Schürmann, Simon Beausaert (2016). What are drivers for informal learning? European Journal of Training and Development, 40, 130-154.

Guido Schwerdt, Dolores Messer, Ludger Woessmann, Stefan Wolter (2012). The impact of an adult education voucher program: Evidence from a randomized field experiment, Journal of Public Economics, 96, 569-583.

SER (2002). Het nieuwe leren: Advieds over een leven lang leren in de kennisdeconomie, Advies 02/10, Den Haag.

SER (2017). Leren en ontwikkelen tijdens de loopbaan. Een richtinggevend advies, Advies 17/04, Den Haag.

SER (2019). Inventarisatie Leven Lang Ontwikkelen in de sociale zekerheid, Advies 19/16, Den Haag.

SER (2020). Private scholingsmiddelen, SER-Advies 20/10, Den Haag.

SER (2020b). Voortgangsrapportage SER Actie-agenda Leven Lang Ontwikkelen: Najaar 2019 - najaar 2020, Den Haag.

SER (2021). Perspectief op Herstel, Advies van de Denktank Coronacrisis, Den Haag.

Gijs de Vries (2019). IKwilverderleren.nl Haalbaarheidsonderzoek naar een digitaal scholingsplatform, Den Haag.

Martin Zimmerman (1982). Learning Effects and the Commercialization of New Energy Technologies: The Case of Nuclear Power, Bell Journal of Economics, 13, 297-310. 
